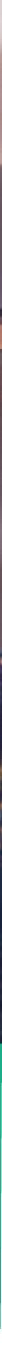

\title{
POLICY BRIEF ON \\ RECENT DEVELOPMENTS IN YOUTH ENTREPRENEURSHIP
}

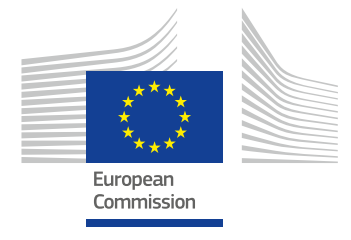


The opinions expressed and arguments employed herein do not necessarily reflect the official views of the organisation or of the governments of its member countries or those of the European Union.

This document and any map included herein are without prejudice to the status of or sovereignty over any territory, to the delimitation of international frontiers and boundaries and to the name of any territory, city or area.

1. Note by Turkey:

The information in this document with reference to 'Cyprus' relates to the southern part of the island. There is no single authority representing both Turkish and Greek Cypriot people on the island. Turkey recognises the Turkish Republic of Northern Cyprus (TRNC). Until a lasting and equitable solution is found within the context of the United Nations, Turkey shall preserve its position concerning the 'Cyprus issue'.

2. Note by all the European Union Member States of the OECD and the European Commission:

The Republic of Cyprus is recognised by all members of the United Nations with the exception of Turkey. The information in this document relates to the area under the effective control of the Government of the Republic of Cyprus.

\section{Acknowledgements}

This paper was drafted by David Halabisky under the supervision of Jonathan Potter, both of the Centre for Entrepreneurship, SMEs, Regions and Cities (CFE) of the Organisation for Economic Co-operation and Development (OECD). An expert paper providing material for this policy brief was prepared for the OECD by Professor Karl Wennberg of Linköping University and Michel Elmoznino Laufer of the Create Business Incubator. This paper benefited from input and suggestions from the European Commission, notably Suvi Lammi, Guy Lejeune, Kathrin Riedler and Shadim Viratham of the Directorate-General for Employment, Social Affairs and Inclusion. Additional feedback and suggestions were provided by Karen Maguire, Acting Head of the Local Employment, Skills and Social Innovation Division of the OECD CFE.

This paper was prepared as part of the programme of work of the OECD Local Economic and Employment Development (LEED) Programme of the Centre for Entrepreneurship, SMEs, Regions and Cities. It is part of a series of policy briefs on inclusive entrepreneurship produced by the OECD Centre for Entrepreneurship, SMEs, Regions and Cities and the European Commission Directorate-General for Employment, Social Affairs and Inclusion. This work is led by Jonathan Potter with David Halabisky and Cynthia Lavison of the OECD.

The links in this publication were correct at the time the manuscript was completed.

(C) Cover photo: Shutterstock

Reuse is authorised provided the source is acknowledged. The reuse policy of European Commission documents is regulated by Decision 2011/833/EU (OJ L 330, 14.12.2011, p. 39).

For any use or reproduction of photos or other material that is not under the OECD/EU copyright, permission must be sought directly from the copyright holders.

More information on the European Union is available on the internet (http://europa.eu).

More information on the OECD is available on the internet (http://www.oecd.org)

Luxembourg: Publications Office of the European Union, 2020

PDF ISBN:978-92-76-13356-8 ISSN:1977-5342 KE-BE-19-001-EN-N

(c) OECD/European Union, 2020 


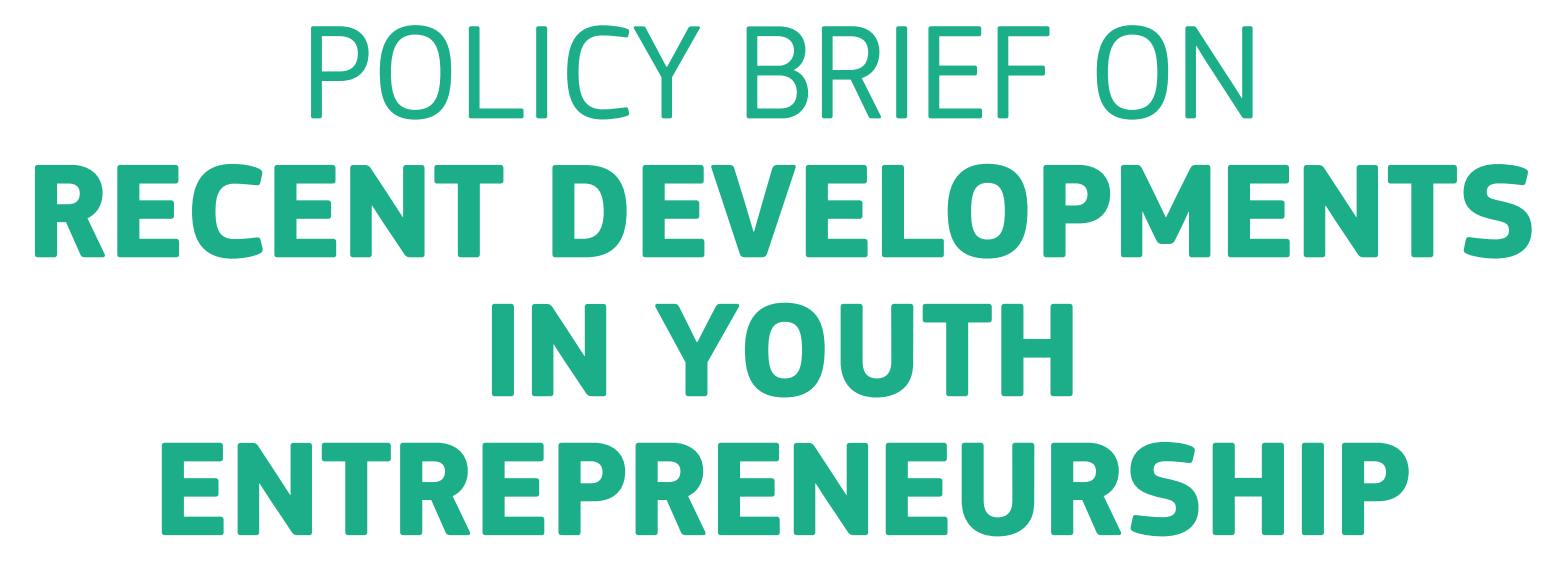




\section{CONTENTS}

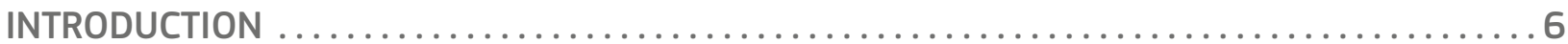

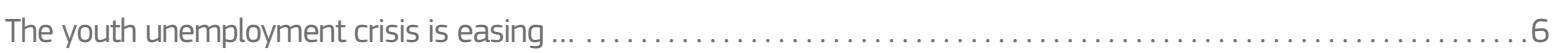

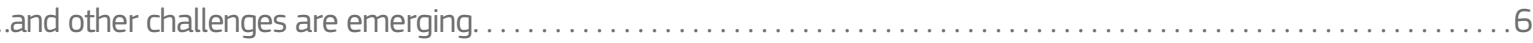

WHAT IS THE POTENTIAL FOR YOUTH ENTREPRENEURSHIP? . . . . . . . . . . . . . . . 7

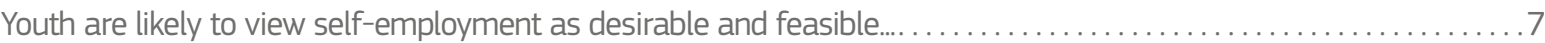

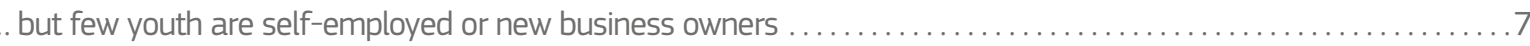

Youth entrepreneurs tend to operate in markets with low growth potential..........................

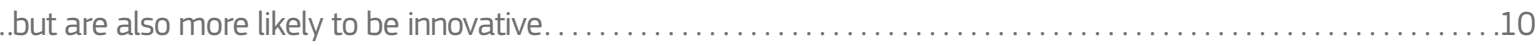

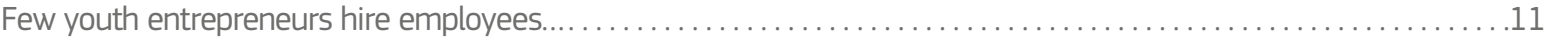

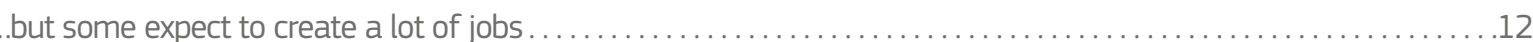

WHAT CHALLENGES DO YOUTH FACE WHEN STARTING A BUSINESS?..................14

Low levels of awareness and few entrepreneurship role models . . . . . . . . . . . . . . . . . . . . . . . . . 14

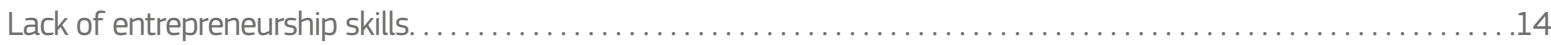

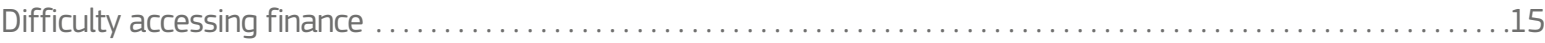

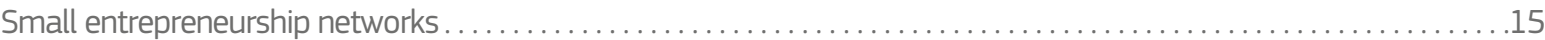

WHAT CAN POLICY DO TO SUPPORT YOUTH IN ENTREPRENEURSHIP? . . . . . . . . . . . 16

1. Promote and stimulate entrepreneurship with role models and business competitions .................16

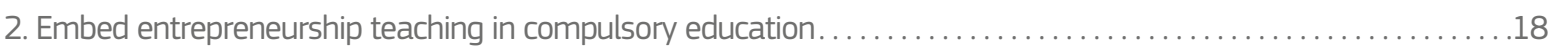

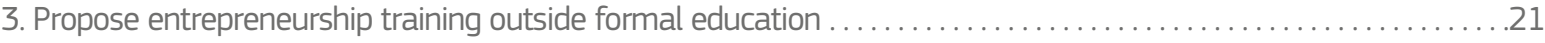

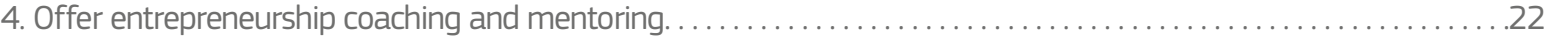

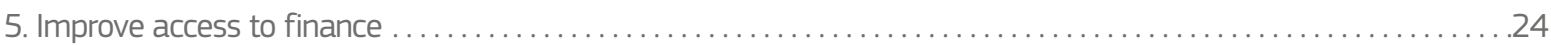

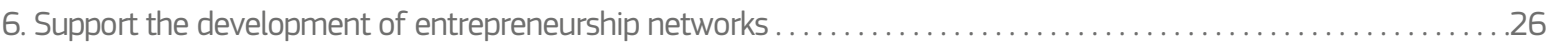

KEY CONSIDERATIONS FOR DESIGNING YOUTH ENTREPRENEURSHIP POLICIES AND

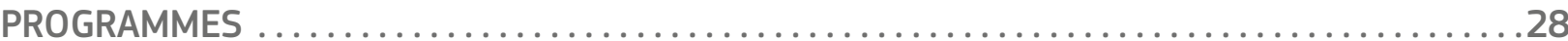

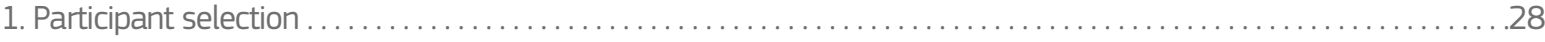

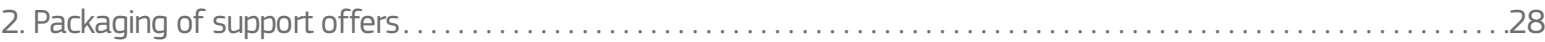

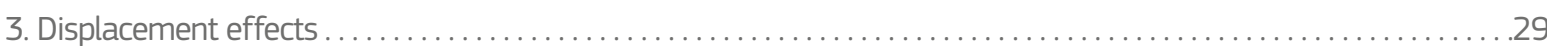

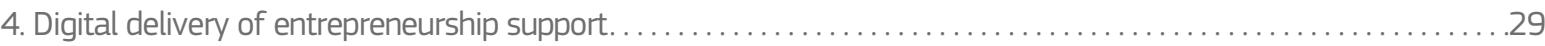

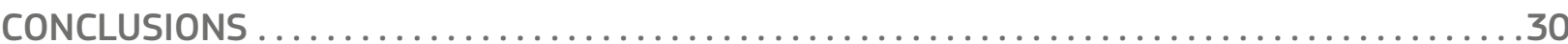

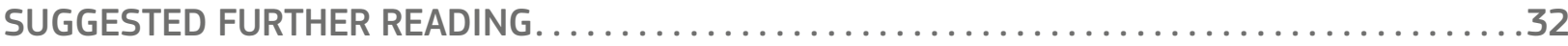

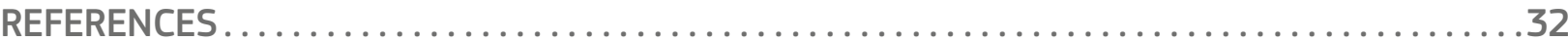




\section{KEY MESSAGES}

- While the youth unemployment crisis has not been fully solved, youth unemployment in the European Union has fallen from its recent peak. Consequently, youth entrepreneurship policy is increasingly emphasising the quality rather than the quantity of businesses created as well as the pathways generated to better opportunities in the labour market.

- Nearly half of young people say they would prefer entrepreneurship over working as an employee. However, young people are much less likely than adults to be self-employed. Youth entrepreneurs face obstacles in the areas of awareness, skills, finance and networks for entrepreneurship. They are also often disadvantaged by their lack of experience in the labour market and lack of a credit history.

- Public policy can address many of the market and institutional failures impeding youth entrepreneurship by increasing awareness about the potential of entrepreneurship, embedding entrepreneurship teaching at all levels of education, offering training and coaching outside of education, improving access to finance and supporting the development of entrepreneurship networks for young people.

- Policy makers should avoid trying to select "winners" for support, since it is hard to anticipate which start-ups will be sustainable. Instead, good practice policy examples show that it can be effective to offer support in stages, with entrepreneurs leading successful projects becoming eligible for follow up support.

- The effectiveness of policy support is greater where packages combine finance with support for advice, training and networking. Policy should be aware of the possibility of displacement effects, seeking to assess displacement in evaluations and to steer entrepreneurs away from excess supply sectors. The potential of digital technologies for some aspects of programme delivery should also be explored.

- It is important to recognise that entrepreneurship is not suitable for everyone. Policy makers should not expect that everyone who participates in an entrepreneurship policy initiative will go on to create a business. However, they may still obtain benefits for subsequent labour market attachment. 


\section{The youth unemployment crisis is easing ...}

One of the greatest policy challenges of the past decade for European Union (EU) countries has been the youth unemployment crisis. At the EU-level, the youth unemployment rate peaked in 2013 at $23.7 \%$, but it was much higher in several Member States such as Greece (58.3\%), Spain (55.5\%) and Croatia (50.0\%). In Italy, the youth unemployment rate peaked a year later at $42.7 \%$. At the same time, the number of youth who were not in employment, education or training (i.e. NEETs) was also increasing rapidly.

This context led to a range of policy actions in the EU, including the EU's Youth Guarantee (European Union, 2013 $3_{[1]}$ ), which was a commitment by all EU Member States in the form of a Council Recommendation. It aims to ensure that all young people under the age of 25 years old receive a good quality offer of employment, continued education, apprenticeship, or traineeship within four months of becoming unemployed or leaving formal education. The Youth Employment Initiative (YEI) is one of the main financial instruments used to implement Youth Guarantee schemes in Member States. It was launched in 2012 and supports youth living in regions where youth unemployment is higher than $25 \%$. The YEI provides financial resources to complement actions funded by national budgets in Member States, as well as those supported by EU funds, notably the European Social Fund (ESF). In 2017, the Council and the Parliament agreed to increase the budget of the YEI by EUR 2.4 billion for eligible Member States for the period 2017-20, bringing the total budget to EUR 8.8 billion for 2014-20 (European Commission, 2018 ${ }_{[2]}$ ).

Although the youth unemployment challenge has not yet been fully resolved, youth unemployment has dropped back to pre-crisis levels (i.e. 2007) in most Member States. Moreover, the proportion of youth (15-29 years old) that are not in employment, education or training (i.e. NEETs) has declined in the EU since 2011 , falling from $15.4 \%$ to $13.4 \%$ in 2017 (Eurostat, $2018_{[3]}$ ). However, it must be recognised that these trends vary greatly at the regional level and many regions continue to face high levels of youth unemployment. Moreover, labour market participation rates for youth continue to decline, having fallen nearly 10 percentage points over the last decade in the EU (Eurostat, 2018 $8_{[3]}$ ).

Youth unemployment and delayed entry into the labour market are a concern for policy makers because the short- and longterm consequences can be great. The long-term impacts include serious negative effects on earnings and employment opportunities, even after 20 years (Schmillen and Umkehrer, $\left.2017_{[6]}\right)$. Moreover, prolonged periods without a job can reduce civic engagement, lower trust in society and other citizens and potentially lead young people into crime (Carcillo et al., $\left.2015_{[7]}\right)$. Youth unemployment also has a substantial cost to economies. For example, recent estimates suggest that NEETs aged 15 to 29 years old cost the EU economy EUR 142 billion per year (Eurofound, 2019 $9_{[8]}$ ).

\section{...and other challenges are emerging}

In parallel, a number of structural changes are unfolding in the labour market. A growing number of workers have non-standard work arrangements, including part-time work and self-employment. These trends vary across regions (OECD, 2018 $\left.{ }_{[9]}\right)$.

Non-standard work has increased for all age groups, but affects youth disproportionately - in 1995, 23\% of young employees that were 25-39 years old had non-standard contracts and this increased to 36\% in 2016 (European Commission, 2017 $[10])$. This is driven by increases in part-time employment and temporary employees (Eurostat, 2018 $8_{[3]}$ ), which were largely involuntary (European Commission, $\left.2017_{[10]}\right)$.

In addition, the emergence of the "gig" economy presents new challenges for policy makers, including "false" selfemployment, i.e. working arrangements where individuals are hired as self-employed workers rather than employees to avoid regulations, taxation and unionisation. This type of work disproportionately impacts youth since they are the most active in the "gig" economy. These types of working arrangements can have negative impacts on both workers and firms, so many governments are seeking to minimise this type of work, notably reducing the fiscal and regulatory gaps between different forms of employment.

Youth entrepreneurship policy can be part of the suite of policy actions used to help youth enter and be active in the labour market. While entrepreneurship is not suitable for all youth, some may be able to create quality jobs for themselves and possibly others. For those who decide not to pursue entrepreneurship or whose projects fail, youth entrepreneurship programmes can still be beneficial because they will be able to grow their networks, build entrepreneurial mindsets and gain experience and skills that could be used to help secure employment (European Commission, forthcoming $\left.{ }_{[11]}\right)$. 


\section{WHAT IS THE POTENTIAL FOR YOUTH ENTREPRENEURSHIP?}

\section{Youth are likely to view self-employment as desirable and feasible...}

Youth are more likely than adults to indicate that they prefer self-employment to working as an employee. Surveys suggest that nearly half of youth report a preference for selfemployment over working as an employee, whereas about one-third of people over 40 years old report this (European Commission, 2013 ${ }_{[12]}$ ).
Moreover, youth are also likely to report that it would be feasible. International surveys suggest that about $40 \%$ of youth (15-24 years old) believe that self-employment would be a feasible activity in the next five years, regardless of whether they were interested in pursuing it (European Commission, $2013_{[12]}$ ). This proportion was slightly above that of older cohorts - about one-third for those 40-54 years old and onesixth for those 55 years old and above.

\section{... but few youth are self-employed or new business owners}

Despite the enthusiasm for self-employment, relatively few young people are self-employed. In 2017, 6.6\% of working youth (20-29 years old) in the EU were self-employed, which was less than half of the rate for the overall proportion (for adults $15-64$ years old) $-13.7 \%$ (Figure 1). In 2017, the youth self-employment rate was the highest in Greece (13.5\%), Italy (13.4\%) and Romania (11.3\%). The self-employment rates for youth were the lowest in Ireland (2.9\%) and Germany (3.0\%).

A different way to measure entrepreneurship activities is to look at the proportion of youth who successfully started a new business. Survey data from the Global Entrepreneurship Monitor (GEM) show that during the period 2013-17, about three percent of youth (18-30 years old) in the EU successfully launched a new business or managed one that was less than 42 months old (Figure 2).

The GEM data indicate that at the EU-level, youth were more likely than adults to start or manage a new business over this period. The EU countries where youth were the most active in entrepreneurship were Lithuania (7.9\%), Latvia (7.7\%), Romania (7.0\%), Netherlands (7.0\%), and Estonia (6.2\%). These were also the countries with the highest new business rates for the overall population.
It is clear from the self-employment and GEM data that the two measures are related since many countries with high selfemployment rates also have high new business ownership rates. However, there are exceptions such as Italy. These differences can often be explained by looking at the types of businesses operated by youth entrepreneurs. Some types of businesses are less likely to be captured by labour force survey questions while others are not likely to be picked up by the GEM questionnaire. In Italy, self-employed youth are overrepresented in Accommodation and food services, as well as Arts, entertainment and recreation. These self-employed youth may not see themselves as "entrepreneurs" and therefore may not self-identify as such in the GEM survey. 
Figure 1. Few youth are self-employed

Proportion of working people that are self-employed, 2017

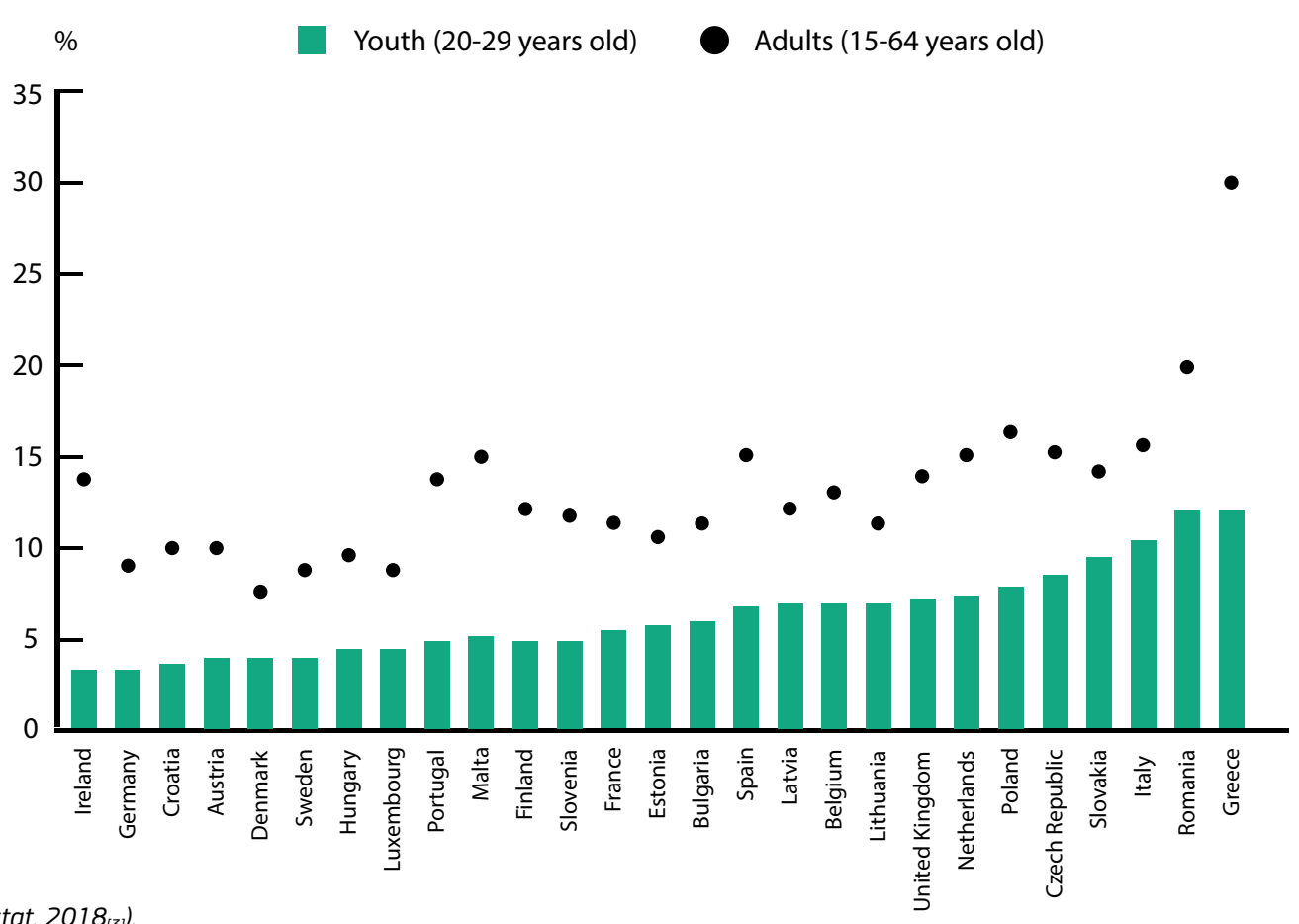

Source: (Eurostat, 2018 $8_{(3)}$.

Figure 2. Youth are active as new business owners

Proportion of the population that are currently an owner-manager of a new business that has paid salaries, wages or any other payments to the owners for more than three months, but not more than 42 months, 2013-17

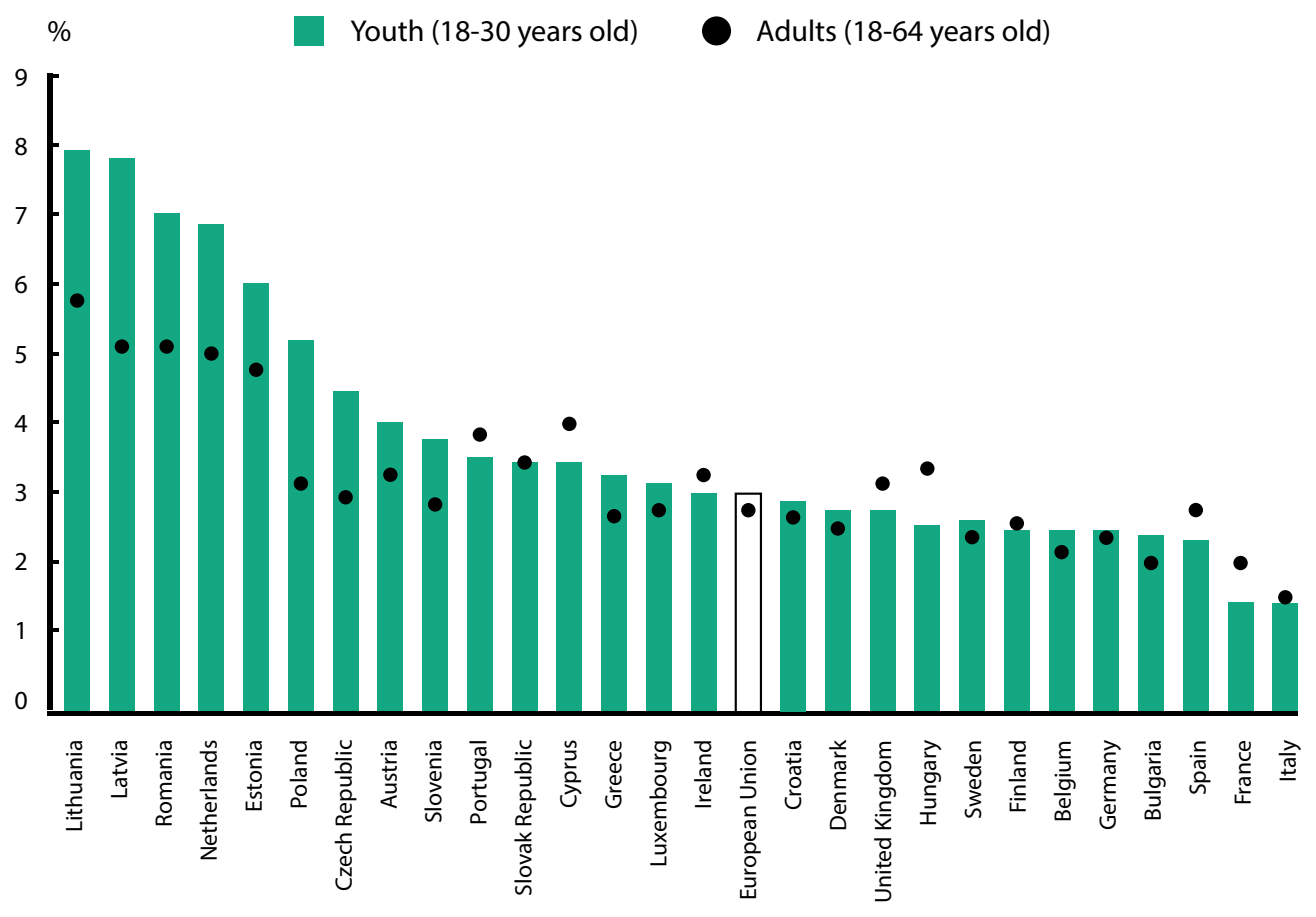

Note: The European Union average excludes Malta because it is not covered by the GEM survey. Source: (Global Entrepreneurship Monitor (GEM), 2018 $\left.{ }_{[13]}\right)$. 


\section{Youth entrepreneurs tend to operate in markets with low growth potential...}

On average, youth entrepreneurs have different motivations for starting businesses to adults. They are slightly more likely than the overall population of entrepreneurs to report that they started their business because they could not find any opportunities as employees (Figure 3).

Figure 3. Youth entrepreneurs are more likely to have started their business out of "necessity"

Proportion of new youth entrepreneurs that started their business due to a lack of employment opportunities, 2013-17

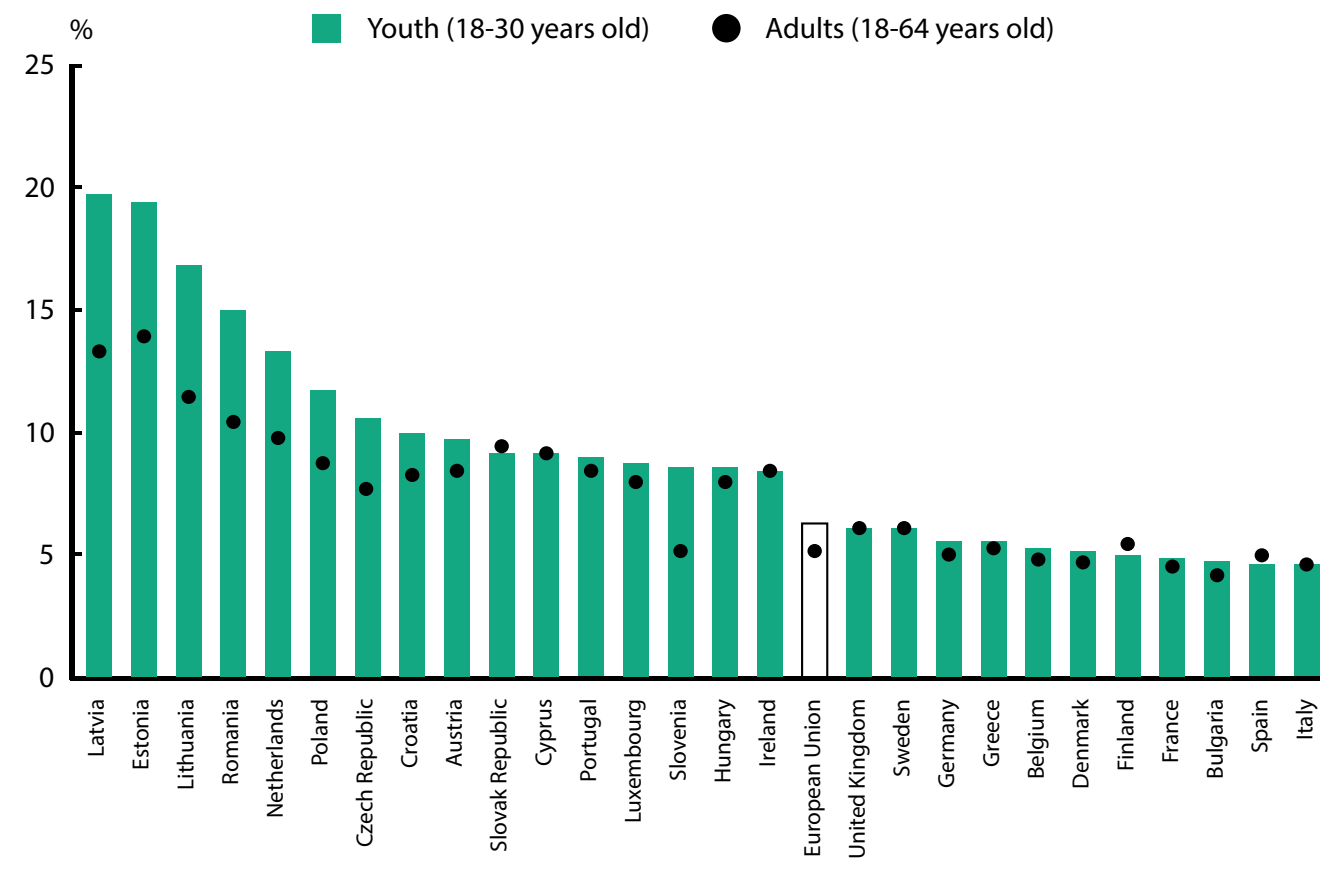

Note: The European Union average excludes Malta because it is not covered by the GEM survey. Source: (Global Entrepreneurship Monitor (GEM), 2018 $\left.{ }_{[13]}\right)$.

Youth entrepreneurs also tend to operate less capital-intensive businesses and in markets that feature price competition rather non-price competition (e.g. differentiated products, brand recognition). Self-employed youth are over-represented in the Construction, Other service (e.g. washing and (dry-)cleaning of textiles, hairdressing, beauty treatment) and Arts sectors $\left(\mathrm{OECD} / \mathrm{EU}, 2017_{[14]}\right)$. These sectors tend to have low entry barriers so it is easier for youth entrepreneurs to enter with little capital or experience.
Self-employed youth (20-29 years old) were as likely as those working as employees to have completed a tertiary education in 2017 (Figure 4). Youth that completed upper post-secondary non-tertiary education were more likely to work as employees, but those who had less than lower secondary education were more likely to be self-employed. There were also some gender differences. Young women that were self-employed were more likely to have completed tertiary education (46.5\%) than selfemployed young men (26.8\%) and young women working as an employee (40.8\%). 
Figure 4. Self-employed youth have similar educational attainments as employees

Distribution of self-employed and employees (20-29 years old) by education al attainment, 2017

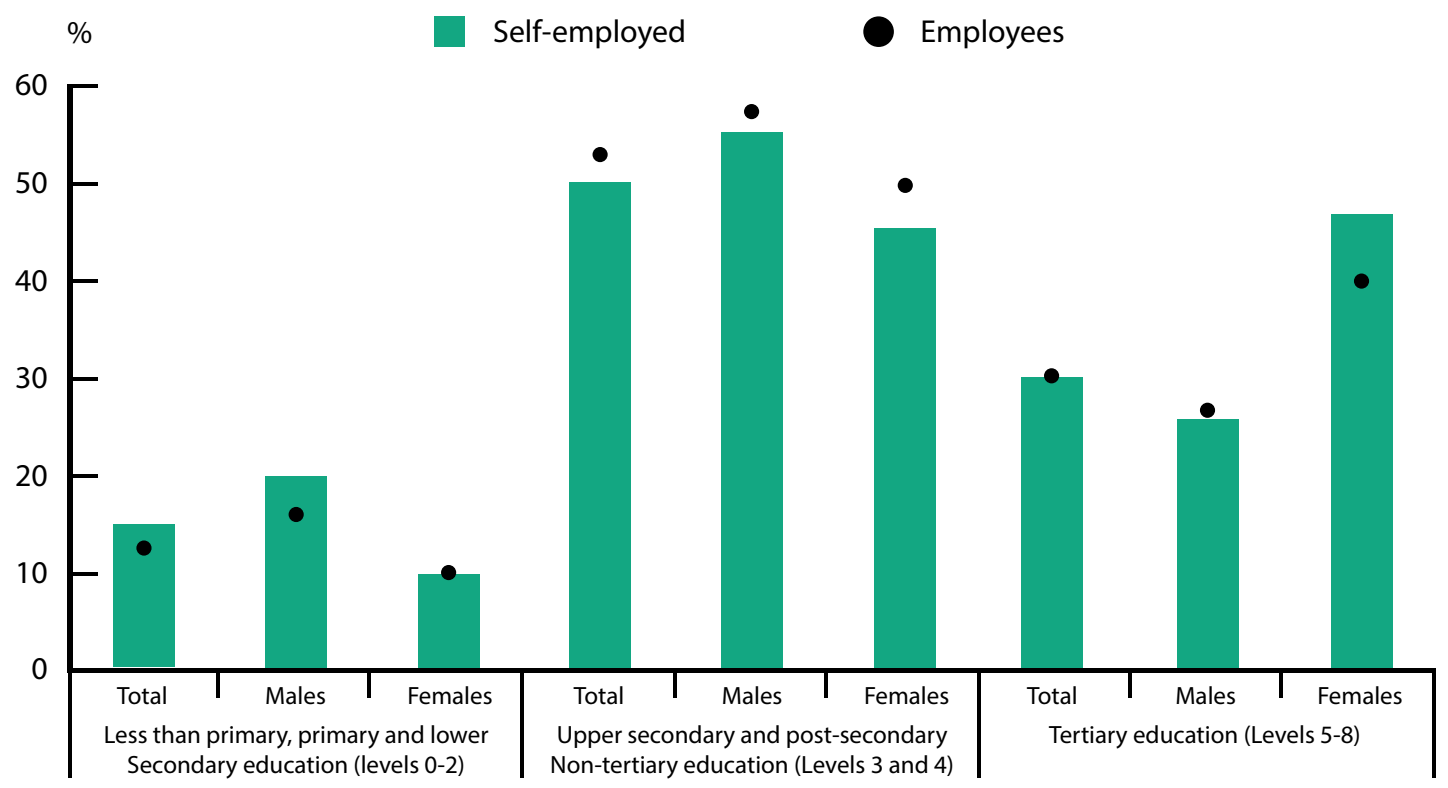

Source: (Eurostat, 2018 $\left.8_{[3]}\right)$.

\section{...but are also more likely to be innovative}

Youth entrepreneurs (18-30 years old) appear to be more likely to report introducing new products and services (Figure 5). Nearly one-third of new youth entrepreneurs (29.7\%) indicated that their business offered products or services that their customers find to be new and unfamiliar between 2013 and 2017, which was slightly above the proportion of new entrepreneurs overall. 
Figure 5. Youth entrepreneurs are more likely to be innovative

Proportion of new entrepreneurs that offer products or services that their customers find to be new and unfamiliar, 2013-17

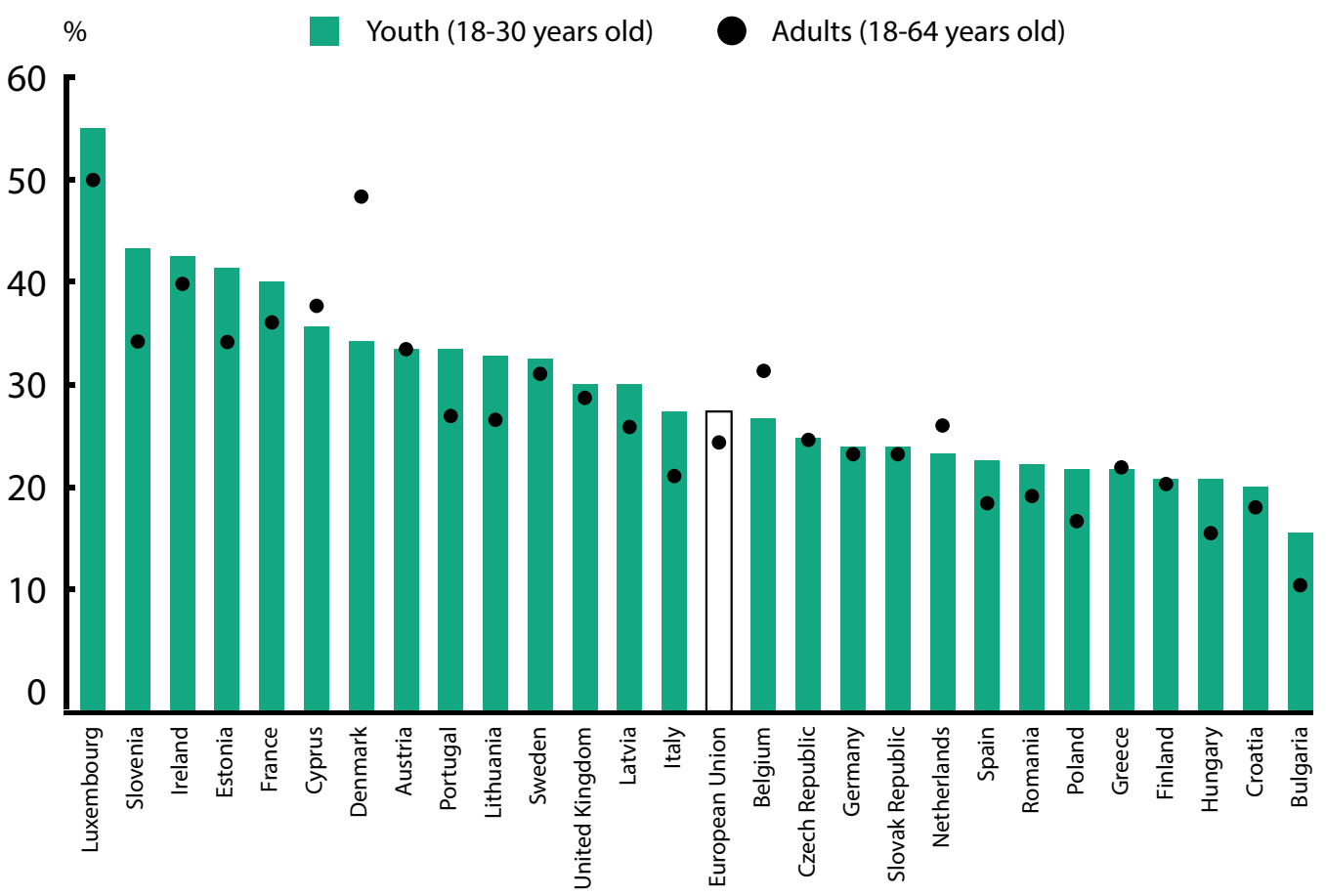

Note: The European Union average excludes Malta because it is not covered by the GEM survey. Source: (Global Entrepreneurship Monitor (GEM), 2018 ${ }_{[133)}$ ).

\section{Few youth entrepreneurs hire employees...}

It appears that about one-in-ten self-employed youth had at least one employee, which was well below the proportion of all self-employed people that had employees - just under 30\% (OECD/EU, 2017 ${ }_{[14]}$ ).

While youth entrepreneurs are less likely to hire employees, they appear to be quite likely to work in teams (Figure 6). Over the period $2013-17,21 \%$ of youth entrepreneurs (1830 years old) indicated that they had started their business in a team of three or more people. This was slightly above the proportion for all entrepreneurs $-18.5 \%$. Youth entrepreneurs in Slovenia (33.1\%), Hungary (31.4\%), and Ireland (31.0\%) were the most likely to operate in teams, while those in the Netherlands (11.4\%), Italy (10.9\%), and Poland (8.8\%) were the least likely. 
Figure 6. Youth entrepreneurs are more likely to operate in teams of three or more

Proportion of new entrepreneurs that operate in teams of three or more, 2013-17.

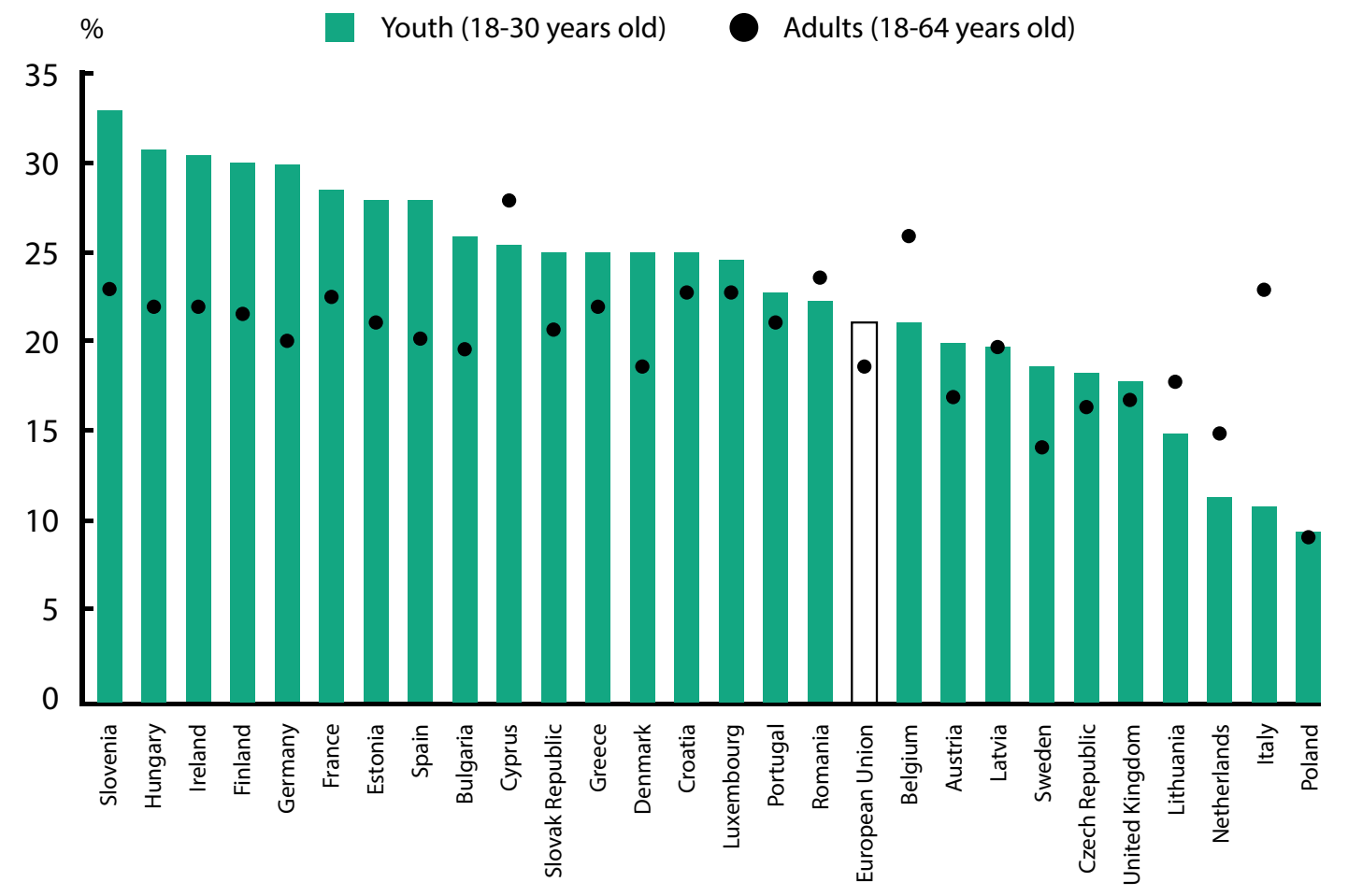

Note: The European Union average excludes Malta because it is not covered by the GEM survey Source: (Global Entrepreneurship Monitor (GEM), 2018 ${ }_{[13]}$ ).

\section{...but some expect to create a lot of jobs}

About one-in-ten new youth entrepreneurs (18-30 years old) in the EU believed that they will create at least 19 new jobs over the next five years between 2013 and 2017 (Figure 7). This was about equal to the proportion of all entrepreneurs in the EU who reported (9.8\%), but was slightly lower than in other regions of the world, such as North America.
New youth entrepreneurs were the most likely to expect to create a high number of jobs in Hungary (20.6\%) and Romania (20.0\%), and the least likely in Greece (3.3\%) and Bulgaria (1.2\%). It is important to note that expected job creation does not necessarily translate into actual jobs created, and it is likely that youth entrepreneurs overestimate their business management abilities and underestimate the challenges that they are likely to encounter. 
Figure 7. Youth entrepreneurs are more likely to expect to create a substantial number of jobs Proportion of new entrepreneurs that expect to create at least 19 jobs over the next five years, 2013-17

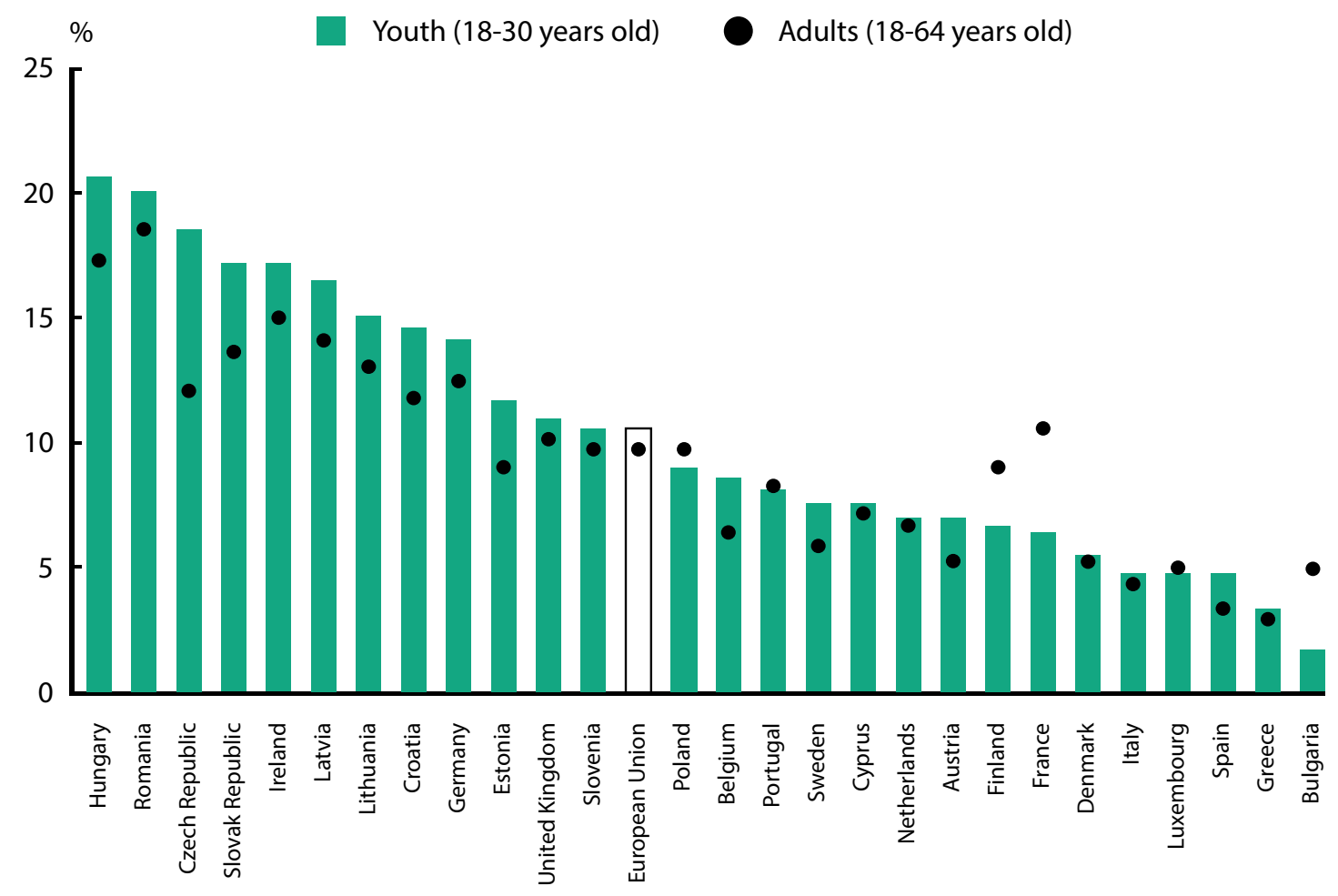

Note: The European Union average excludes Malta because it is not covered by the GEM survey.

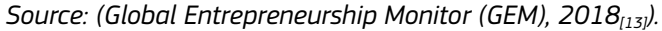




\section{WHAT CHALLENGES DO YOUTH FACE WHEN STARTING A BUSINESS?}

\section{Low levels of awareness and few entrepreneurship role models}

Due to their limited work experience and small professional networks, many young people have had little contact with successful entrepreneurial role models who can provide support and business advice (Schøtt, Kew and Cheraghi, 2015 ${ }_{[15]}$ ). Those with parents that are entrepreneurs are much more likely to be entrepreneurs because they have greater social capital and access to tacit knowledge (Geldhof et al., 2014 $4_{[16]}$ ). Experiments have shown that students in higher education who are exposed to entrepreneurial mentors have an increased likelihood of becoming entrepreneurs, particularly those with parents who are not entrepreneurs (Eesley and Wang, 2017 $[17]$ ).

In addition, young people may also lack awareness of the availability of programmes that support new business ventures.

\section{Lack of entrepreneurship skills}

Few young individuals believe they have the skills to become entrepreneurs. Overall, $36.3 \%$ of youth (18-30 years old) reported that they had the skills and knowledge to start a business during the period 2013-17 (Figure 8). This was below the proportion of adults that report having the skills for business creation $-41.9 \%$.

The proportion of youth reporting having the knowledge and skills for business creation ranged from 25.2\% in Denmark to $50.6 \%$ in Poland. Youth were less likely than adults to believe that they had the skills for entrepreneurship in all countries, except Latvia, Romania, the Czech Republic, and Estonia, where they were as likely as adults to report having entrepreneurship skills.

There is also a small gap between many EU countries and non-EU countries such as Canada and the United States (US). Slightly more than $40 \%$ of youth in Canada and the US selfreported having the skills needed to start a business, which was about 5 p.p. above the EU average (OECD/EU, 2017[14]).
More precisely, this skills gap can be described as lack of skills in the areas of opportunity recognition, business planning, financial management, sales and marketing (European Parliament, $\left.2015_{[18]}\right)$.

Another issue is the lack of appropriate education and training offers to provide a strong foundation to support young people's entrepreneurial ambitions. The European Parliament has emphasised the importance of promoting entrepreneurship in non-formal and informal education as a way of improving early school leavers' employment prospects (European Parliament, 2015 ${ }_{[18]}$ ). 


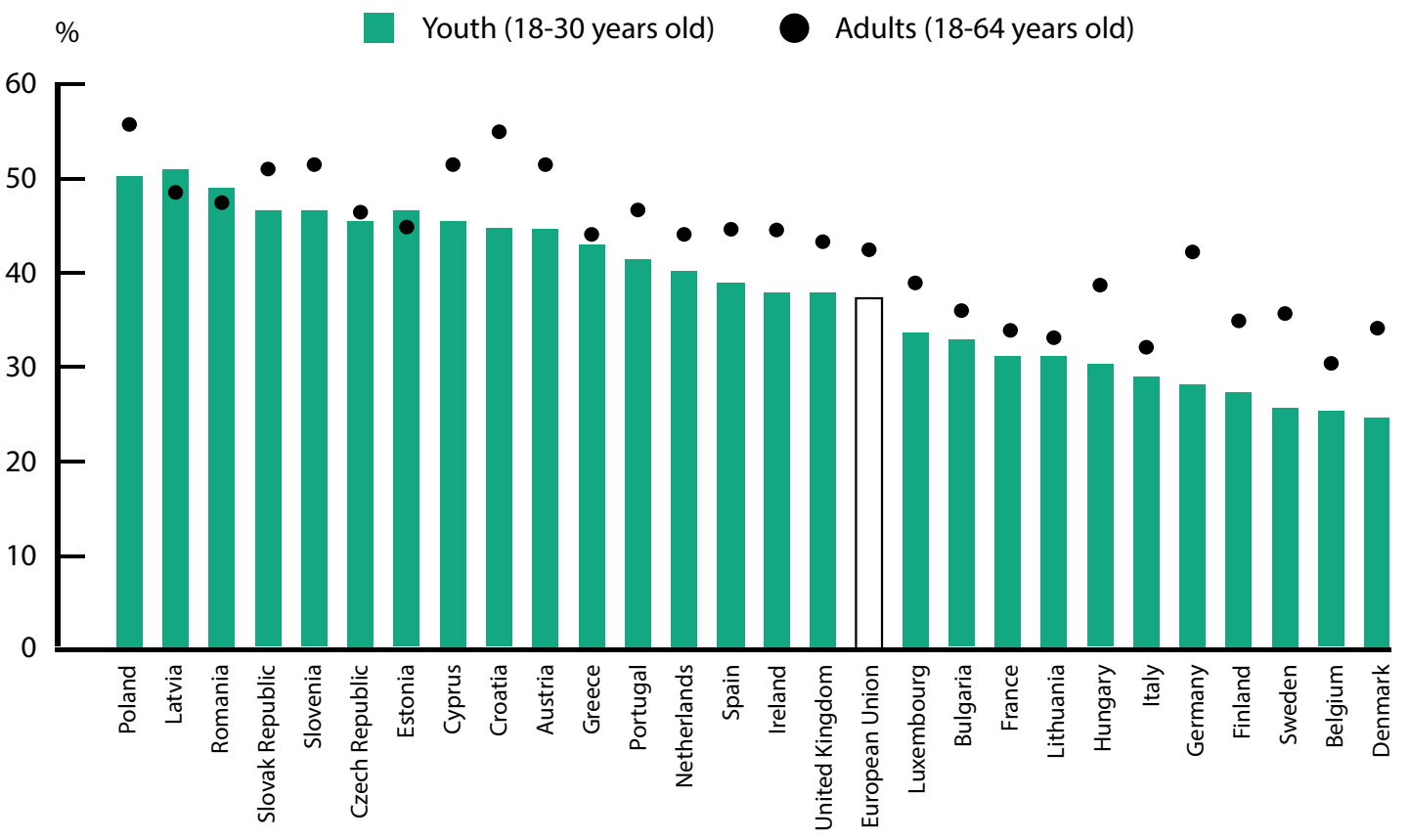

Note: The European Union average excludes Malta because it is not covered by the GEM survey. Source: (Global Entrepreneurship Monitor (GEM), 2018 $\left.{ }_{[13]}\right)$.

\section{Difficulty accessing finance}

The financial crisis of 2008 has increased the difficulty for young entrepreneurs to obtain external financing. According to Eurofound, $82 \%$ of young Europeans indicated that a lack of finance and financial support is the main barrier to making entrepreneurship feasible (Eurofound, $2015_{[19]}$ ). Youth may have more difficulty than older entrepreneurs in obtaining external financing due to their lack of proven experience and lack of personal savings, collateral and credit history (Eurofound, 2016[20] (Schøtt, Kew and Cheraghi, 2015 ${ }_{[15]}$ ).

\section{Small entrepreneurship networks}

Due to their limited work experience, young entrepreneurs have had less time than older entrepreneurs to build a professional network and rely to a larger extent on the support of their family. Social networks are important both for building a customer base and for getting support and encouragement to start a new business (Jones, Brinkley and Crowley, 2015 $5_{[22]}$ ). Social networks may be important as a source of motivation and inspiration for example by having entrepreneurial role models or by receiving support from family and friends.
Younger entrepreneurs have typically had less time than older entrepreneurs to accumulate personal savings that they can invest in starting a new business. Research has shown that the size of the wealth has a positive effect on the newly founded firms' probability of survival (Oreland, 2016 $[21]$ ).

However, professional networks tend to offer more value because they are more likely to provide connections to potential suppliers, customers, and other stakeholders (Hite, 2005 $5_{[23]}$ ) (Davidsson and Honig, 2003 [24]). Without a professional network, it can be difficult for the entrepreneur to identify the range of public actors who may be able to provide funding and support. All this could have negative consequences for the entrepreneur's ability to obtain financing as well as for how they make use of obtained resources (Laufer and Wennberg, 2017 $7_{[25]}$ ). 


\section{W WHT CAN POLICY DO TO SUPPORT YOUTH IN ENTREPRENEURSHIP?}

The rationale for youth entrepreneurship policy is often based on four arguments. First, there is evidence that youth face greater obstacles to business creation and self-employment than older generations. These difficulties stem from market failures and institutional failures, including greater difficulties in accessing resources such as finance. Second, many youth have difficulties entering the labour market and entrepreneurship can provide an alternative route into the labour market alongside employment. Third, economic gains and innovation can be realised by supporting talented youth, including graduates, with high potential business ideas. Finally, entrepreneurship programmes can help youth develop transversal skills that will help them in their career, regardless of whether they go on to start a business.

Policy makers have a number of instruments that they can use to support youth in entrepreneurship and this section explores the main approaches used to encourage and support youth entrepreneurship in the EU.

\section{Promote and stimulate entrepreneurship with role models and business competitions}

IF Goal

Increasing awareness and understanding about entrepreneurship among youth may increase the number of young people that are interested in pursuing it as a full-time or part-time activity, during youth or later in life.

\section{Approach}

The formal education system is one of the most effective ways of promoting youth entrepreneurship, and role models can be promoted through media and online campaigns. However, there is a growing trend towards using more active approaches to engage and inspire youth in entrepreneurship, including business competitions. Regardless of the method, the objective should be to inform youth about the role of entrepreneurship in the economy, what it takes to start and run a business, and inspire them to try it if they are interested in it.

Schools have a critical role in promoting entrepreneurship given that virtually all youth are in school. The formal education system can promote entrepreneurship both by integrating entrepreneurship in education programmes (see policy section 3 for more information on entrepreneurship education) and by developing extra-curricular activities. While many extra-curricular activities are organised by teachers (e.g. entrepreneurship clubs), others can involve a range of other actors from the public, private and non-profit sectors. For example, the Youth entrepreneurship theme year was organised as part of the Helsinki-Uusimaa Regional Programme in Finland (Box 1). As part of the European Commission's European Entrepreneurial Region (EER) project, more than 80 events were organised in the region to increase high school student's exposure to entrepreneurship. 


\section{Box 1. Youth entrepreneurship theme year, Finland}

(f) Target group: Secondary-level students and university students.

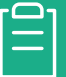

Intervention type: Events to create positive attitudes towards entrepreneurship.

Description: The theme year was part of the European Entrepreneurial Region (EER) project that was set up by the European Commission with the support of other EU stakeholders such as Eurochambres. The aim of this ongoing project is to identify and support EU regions that demonstrate an innovative entrepreneurial policy strategy.

The Youth entrepreneurship theme year was organised in 2012 in Helsinki-Uusimaa. One of the main motivations for this initiative was a simultaneous decrease in the number of new businesses started in the region and an increase in the number of business closures. Its objective was to

• boost interest in entrepreneurship,

- promote entrepreneurial activity, creativity and spirit,

- develop business know-how,

• create new networks and

- raise awareness of business and innovation activity in the region.

About 80 events were organised as part of the theme year, ranging from large conferences to small networking events.
The events were frequently aimed at youth and students, but some also engaged policy makers and the business community. The majority of the activities tried to inspire youth and to teach them about the potential of a career in entrepreneurship. Online initiatives were animated in parallel through various social media platforms.

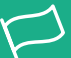

Results achieved: An evaluation assessed the impact of the 2012 theme year of entrepreneurship

in Helsinki-Uusimaa using two surveys of 1598 second-year students who were $17-18$ years old. The evaluation found that young people's perceptions about entrepreneurship became slightly more positive following the theme year. However, it was difficult to directly attribute this change to actions undertaken as part of the theme year as the weak economic context meant that it was difficult to obtain a job. Moreover, there are several other factors that influence attitudes towards entrepreneurship, e.g. culture, media.

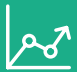

Lessons for other initiatives: The evaluation highlights the impacts that can be achieved in building an entrepreneurship culture through long-term activities and the creation of structures to encourage and support entrepreneurship, including entrepreneurship education, business support organisations, and concrete entrepreneurship policies.

Source: (Rantanen and Järveläinen, 2016 ${ }_{[26]}$ ).
The promotion of role models is important because it makes entrepreneurship tangible through the sharing of experiences. Role models can be offered by providing for speakers at events or in schools, or showcasing the stories of entrepreneurs in media campaigns. To appeal to youth, role models should be selected to demonstrate a range of entrepreneurship activities, including not only innovative technology businesses but also those in other sectors and those with social objectives. It is also important to showcase some young entrepreneurs who other youth may relate better to than adults.
Business competitions can also be beneficial because they can give youth a flavour of what it is like to be an entrepreneur through a short project. There has been an increase in entrepreneurship competitions for youth in the EU (Eurofound, $\left.2016_{[20]}\right)$. The premise of these competitions is that young participants are given a challenge and they are to design a project to respond. This usually involves setting objectives, developing a plan and presenting it to a panel of judges. Some competitions also offer seminars and coaching to participants while they are developing their plans. Winners may be awarded a range of prizes, often including a small amount of funding to support the realisation of the project. 


\section{Embed entrepreneurship teaching in compulsory education}

\section{Fo Goal}

Introducing modules and activities on entrepreneurship at various levels of education can help ensure that children and youth are exposed to entrepreneurship in different ways. This would be expected to deepen young people's understanding about what entrepreneurship is and its role in society. It can also help nurture students' entrepreneurial skills, attitudes and motivations (European Parliament, 2015 $5_{[18]}$ ) and enhance an individual's level of self-efficacy (Schøtt, Kew and Cheraghi, $2015_{[15]}$ ) (Oosterbeek, van Praag and ljsselstein, 2010 $0_{[27]}$. Students participating in entrepreneurship education are more likely to start their own business, and those who have taken some entrepreneurship education are less likely to be unemployed (European Parliament, 2015 $5_{[18]}$ ). For an economy, these students would be expected to help stimulate innovation (European Commission, forthcoming $\left.{ }_{[11]}\right)$ (EU, 2013 $\left.3_{[28]}\right)$.

\section{Approach}

Entrepreneurship education has been promoted to EU Member States through several EU-level strategies and initiatives, including Education \& Training 2020, The Entrepreneurship 2020 Action Plan, and Rethinking Education.

Entrepreneurship education most often takes place in higher education, but also increasingly at the secondary level of education. There are fewer activities at the primary and lower secondary levels. However, research suggests that entrepreneurship education may be particularly important at a young age (Elert, Andersson and Wennberg, 2015 $29 \mathrm{f})$ (Oosterbeek, van Praag and ljsselstein, 2010[27]).

The implementation of entrepreneurship education is uneven across EU Member States. Many countries have partial or specific strategies and approaches for entrepreneurship education. But the lack of common goals and approaches, coupled with fragmented education systems, presents a barrier to the development of a more systematic approach across the EU (European Commission, 2017[30]). Table 1 provides an overview of the approaches to entrepreneurship education used in EU Member States.

Table 1. Overview of Member States' strategic approach to entrepreneurship education

\begin{tabular}{|c|c|c|c|}
\hline Scope & Specific comprehensive strategy & Embedded in broader strategies & Single programmes and initiatives \\
\hline Member State & $\begin{array}{l}\text { Belgium, Denmark, Estonia, } \\
\text { Finland, Sweden, Wales (UK) }\end{array}$ & $\begin{array}{l}\text { Austria, Bulgaria, Croatia, } \\
\text { Cyprus, Denmark, Estonia, } \\
\text { France, Greece, Hungary, Ireland, } \\
\text { Latvia, Lithuania, Luxembourg, } \\
\text { Netherlands, Northern Ireland } \\
\text { (UK), Poland, Romania, Scotland } \\
\text { (UK), Slovakia, Slovenia }\end{array}$ & $\begin{array}{l}\text { Czech Republic, England (UK), } \\
\text { Germany, Italy, Malta, Portugal, } \\
\text { Spain }\end{array}$ \\
\hline
\end{tabular}

Source: Adapted from (European Parliament, 2015 $5_{[18)}$ ) and (European Commission/EACEA/Eurydice, 2016 $6_{[31]}$ ).

Only a minority of the Member States have implemented a specific national strategy for entrepreneurship education. An example is the Strategy for Education and Training in Entrepreneurship in Denmark, which is an example of how entrepreneurship education can be coordinated across the whole education system (Box 2). 


\section{Box 2. "The Strategy for Education and Training in Entrepreneurship" and "Denmark - a nation of solutions", Denmark}

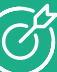

Target group: Students at all levels of education, from primary school to higher education.

$\underline{\square}$ Intervention type: National strategies for entrepreneurship education.

$\{\mathrm{O}$ Description: The Danish government launched The Strategy for Education and Training in Entrepreneurship in 2009. The strategy's main objective was to embed entrepreneurship in all educational levels and set entrepreneurial teaching objectives for primary, upper-secondary (including VET) and higher education. Two other important objectives were to create (i) an institution with the role of providing a coherent national commitment to entrepreneurship education and training, and (ii) a partnership between the four key ministries that have a role in designing and/or implementing entrepreneurship education and training - Ministry for Science, Technology and Innovation; Ministry of Culture; Ministry of Education; and Ministry of Economic and Business Affairs.

The new institution - The Danish Foundation for Entrepreneurship (FFE-YE) - was established in January 2010 as a result of the partnership between the four ministries. It is responsible for promoting entrepreneurship education, funding entrepreneurial projects, and research and analysis in the field of entrepreneurship education. The FFE-YE has supported the development of teacher competences, pedagogical tools, impact measurements Source: (Eurofound, 2016 $[20]$ ) (Eurofound, 2015 $5_{[19])}$ ) and evaluation forms and tests. It continues to develop an overall education model to strengthen the quality of entrepreneurship education.

In 2012, the Strategy for Education and Training in Entrepreneurship was replaced by the new innovation strategy “Denmark - a nation of solutions". The new strategy aimed to improve frameworks and support for business innovation and focused on three areas:

1. Addressing societal challenges through innovation;

2. Translating knowledge into value;

3. Increasing innovation capacity through education.

Results achieved: A 2013 FFE-YE study on the effects of entrepreneurship education at school based on a survey among 2000 students aged 15-16 showed that almost all respondents (95\%) had a positive attitude towards entrepreneurship. Evaluation results show that between 2010 and 2014, FFE-YE succeeded in doubling the number of students that participated in entrepreneurship education.

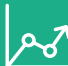
Lessons for other initiatives: This example shows that coherent coordination on entrepreneurship education across a wide range of policy and educational stakeholders through a centralised agency can yield positive outcomes. 
The European Commission emphasises investments in transversal skills in its 2012 Communication Rethinking Education (European Commission, 2012 ${ }_{[32]}$ ). The focus was placed on transversal skills such as critical thinking, taking initiative, solving problems, and working collaboratively. Entrepreneurship skills and mindsets are key transversal skills that contribute to the employability of young people and prepare them for the rapidly changing labour market. The
European Commission recommends that Member States foster entrepreneurial skills through creative ways of teaching from primary school onwards, and that problem-based learning and enterprise links are embedded across all disciplines and tailored to all levels of education. It has developed the Entrepreneurship Competence Framework to support the implementation of entrepreneurship education (Box 3).

\section{Box 3. EntreComp: The Entrepreneurship Competence Framework}

The EntreComp Framework is an initiative by the European Commission to recognise entrepreneurial competences. One of the key objectives of EntreComp is to develop a common conceptual approach, which could support the development of entrepreneurship competences across the EU.

The framework proposes a shared definition of entrepreneurship as a competence and provides a tool for initiatives aiming to improve the entrepreneurial capacity of individuals and organisations in Europe. The framework aims to build consensus around a common understanding of Source: (Bacigalupo et al., 2016 ${ }_{[33\}}$ ) entrepreneurship competence by defining three competence areas, a list of 15 competences, and 442 learning outcomes which current and future initiatives can refer to. The framework can be used as a basis for the development of curricula and learning activities fostering entrepreneurship as a competence.

EntreComp was developed by the Joint Research Centre (JRC) of the European Commission on behalf of the Directorate General for Employment, Social Affairs and Inclusion (DG EMPL).
Governments have an important role in the development of entrepreneurship education. First, they need to ensure that appropriate resources are in place to allow for the development of programmes and introduction of teaching material. This requires sufficient budget allocations, and may also entail the funding of specific initiatives to develop textbooks or activities (e.g. Start-Up Weekends).

Second, sufficient resources are needed to support teachers. This includes the provision of teacher training (both training for new teachers and ongoing professional development opportunities) to help develop entrepreneurial attitudes among teachers and to ensure that they are equipped to work with students (European Commission, 2017[30]). A positive attitude among teachers is an important pre-condition for successfully including entrepreneurship in education. Various approaches are used for teacher training, including experiential learning exercises that emphasise collaboration and innovation, and internships in companies (European Commission, 2017 [30]). Support for teachers could also include the development of teacher networks and good practice observatories.
It is also important to recognise that extra-curricular activities are a critical element of entrepreneurship education. These could include business competitions, student workshops and entrepreneurship clubs. Often these are organised by individual teachers, but some are supported by nongovernmental organisations such as Junior Achievement. Partnerships with businesses and business organisations can be important for designing and delivering effective activities (European Commission/EACEA/Eurydice, 2016 $\left.6_{[31]}\right]$. 


\section{Propose entrepreneurship training outside formal education}

\section{Goal}

Offering an opportunity to acquire entrepreneurship skills to youth outside of formal education is critical to ensure that youth and young adults who are not in school have an opportunity to acquire entrepreneurship skills and mindsets. Most of these programmes focus on delivering the practical business management skills needed to successfully start and manage a new business.

\section{Approach}

Entrepreneurial skills, mindsets and attitudes are frequently built outside the formal education system, reflecting the nature of entrepreneurship as an activity for which expertise is gained largely by experiential learning rather than in traditional classroom education (Elert, Andersson and Wennberg, 2015 [29] ) (Politis, 2015 ${ }_{[34]}$ ).

Entrepreneurship training for youth typically focusses on business creation and is delivered through structured courses taught in-person, thematic workshops, and online classes. Participants can learn about, for example, accounting and finance, law and legal issues, team building and personal development.
One of the key success factors in youth entrepreneurship training programmes is that the trainers are equipped with the knowledge and experience to deliver entrepreneurship modules to youth. They need to have strong communication skills and also be able to motivate and inspire young people.

It is also important to use active learning methods rather than traditional classroom teaching methods. This allows students to gain hands-on experience through games, simulations and short-term projects.

These programmes are often delivered in combination with other types of support such as start-up financing. Evaluation evidence frequently suggests that training is more effective when combined with more intensive individual support such as coaching (see policy section 4 for further discussion) or start-up financing, which can allow the young entrepreneur to launch their project and apply what they are learning. An example of a programme that provides entrepreneurship training (combined with financial support) for youth is the youth entrepreneurship programme in Hungary (GINOP and VEKOP) (Box 4).

\section{Box 4. Youth Entrepreneurship Programme (GINOP and VEKOP), Hungary}

C Target group: Youth under 25 years old, and job seekers up to 30 years old.

$[\varrho]$ Intervention type: Financial support, training and mentoring.

$\{\tilde{O}\}$ Description: The Youth Entrepreneurship Programme was launched in 2014. The programme is delivered as VEKOP in Central Hungary and GINOP in other regions, but they are essentially the same programme. They offer entrepreneurship training and start-up financing. Implementation is done at the regional level, providing flexibility to adapt the programme's content to the local needs.

The programme consists of two components. In the first component (GINOP 5.2.2 and "Be a young entrepreneur in Hungary!"), service providers deliver entrepreneurship training, mentoring, and business counselling, focusing on the development of business plans. In the second component (GINOP 5.2. and VEKOP 8.3.1), participants can apply for a grant of up to HUF 3 million (approximately EUR 10000 ) to cover their start-up costs if they have completed the training programme and have an accepted business plan. However, the youth entrepreneurs must contribute at least 10\% of the start-up financing needed.

The programmes are part of Hungary's Youth Guarantee, so the entry point for youth is through the National Employment Service $\left(O E C D, 2016_{(35)}\right)$. The programmes are co-financed by the European Social Fund.

Results achieved: GINOP and VEKOP aim to provide support to 6500 youth in business creation by the end of 2022. Monitoring data indicate that the GINOP and the VEKOP measures had 1359 applicants up to the end of 2018, with 616 successful project applications receiving the support so far - about $9.4 \%$ of the target indicator. This is below the initial target due to some implementation delays. The uptake of the programme is expected to increase following programme adjustments that come into force in mid-2019, including relaxed entry requirements and increased budget.

Lessons for other initiatives: The strength of this approach is that it is an integrated offer that is tailored to meet the needs of individual participants. Implementation approaches are determined at the regional level, allowing the programme to be tailored for local economic conditions. 


\section{Offer entrepreneurship coaching and mentoring}

Goal

The individual support offered by coaches and mentors aims to improve the chances of success for young people in business creation or business development. This can help compensate for a lack of experience in the labour market, as well as provide encouragement and inspiration.

\section{Approach}

Entrepreneurship coaching and mentoring are often discussed together, but many people make a distinction between the two $\left(\right.$ OECD/EU, 2014 $\left.{ }_{[36]}\right)$. Coaching usually refers to a short-term relationship that is focussed on developing entrepreneurship skills or addressing a specific business challenge. Mentoring is typically a longer-term relationship that has a greater emphasis on personal development rather than focussing on business development.

Coaches and mentors typically provide advice and guidance to youth entrepreneurs before business creation and during the early stages of business development. The advice is often based on their experience, and provided as needed to the young entrepreneur. However, it could include a more formal development plan that sets out milestones for the entrepreneur and their business. Another important role for coaches and mentors is to provide young entrepreneurs with access to their networks.

Business advisors, coaches and mentors can be paid professionals or volunteers. When volunteers are used, it is necessary to ensure that there are sufficient incentives for their participation. This could include, for example, networking events for advisors or public recognition (e.g. awards). Programmes that recruit volunteer advisors and mentors should ensure that the volunteers also have appropriate experience and skills to work with youth. This includes having strong communication skills.

One of the key success factors for entrepreneurship coaching and mentoring relationships is effectively matching young entrepreneurs with a coach or mentor who is equipped to address their needs. This usually involves each party outlining their objectives and responsibilities in writing at the beginning of the relationship. It is helpful to have coaches and mentors with experience in a related sector because it can help facilitate the quick establishment of trust with the entrepreneur.

Another important success factor is the accessibility of the coach or mentor. When working with youth, it will be important that coaches and mentors are responsive. It is also critical that they can communicate through relevant channels such as email and text messages.

In setting up entrepreneurship coaching and mentoring programmes for youth entrepreneurs, policy makers should seek to develop partnerships with business professionals and organisations that have a history of working with youth Often coaches and mentors are identified with open calls by partner organisations.

Coaching and mentoring programmes can seek to improve the quality of the relationships by offering training to the coaches and mentors. This could include training on communication with youth and tips for managing the relationship.

Programme evaluations tend to be positive for coaching and mentoring programmes - the intensive individual support typically improve the sustainability of the business (Jones, Brinkley and Crowley, 2015 2 [22]). Strong support after business creation is particularly important for improving the survival rates of businesses created by youth. This is demonstrated well by the Prince's Trust Enterprise Programme, which offers coaching and mentoring along with progressive amounts of financing to "unbankable" youth (Box 5).

It is also important to caution that coaching and mentoring programmes should not provide such intensive support that the entrepreneur becomes dependent on their coach or mentor for the operation of their business. This will limit the young entrepreneur's capacity to operate their business after the coaching or mentoring relationship is finished. To address this, it can be helpful to set a limit for the length of the coaching or mentoring. 


\section{Box 5. The Prince's Trust Enterprise Programme, United Kingdom}

(C)

Target group: Unemployed youth that are $18-30$ years old.

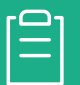

Intervention type: Mentoring and financial support.

Description: The Prince's Trust Enterprise Programme is an example of a long-standing and successful entrepreneurship programme for young people.

The programme features a phased approach that is delivered in four stages:

1. Meet the team: This is an information session that allows interested participants to learn more about the programme.

2. Explore: This is a four-day workshop that covers goal setting, personal finance, legal structures, marketing, pricing, taxation, and business plans.

3. Building your business: This phase includes a mentor that will provide individual support to help with market research, and developing business and financial plans. For those who successfully develop a business plan, they may be eligible for a "Will it Work" grant of up to GBP 250 (approximately EUR 290) to test their business idea.

4. Launch: Before launching their business, participants present their business plans to the Business Launch Group for feedback on the viability of the business plan. Those with business plans that are "approved" can access individual mentoring for up to two years and can access discounted business services for three years. In addition, participants can access a low interest start-up loan of up to GBP 5000 (approximately EUR 5 840) and small start-up grants for those in special circumstances.

One of the key elements of the programme is the coaching and mentoring. Business mentors are volunteers who commit to about four to six hours per month for a minimum of two years. The role is to meet with the young entrepreneur and to act as a sounding board for them to share their thoughts, concerns and successes. Coaches and mentors help young entrepreneurs develop and grow their business as well as empower them to make their own decisions about the business. They are identified through open calls on the programme website. The strong reputation of the programme helps to make the role attractive for prospective coaches and mentors.

The Enterprise Programme has two unique features relative to other youth entrepreneurship programmes. First, the programme now offers the four-day programme as online modules, and also offers e-mentoring. Second, participants that start the programme but decide that entrepreneurship is not a suitable activity can access mentoring support to help identify other employment and/or learning opportunities.

Results achieved: Since 1983, Prince's Trust has supported over 80000 young people to set up businesses. A recent evaluation of business survivability was conducted between October 2015 and January 2016 with phone surveys of 550 entrepreneurs starting in 2012 13 (Wavehill, 2016 $\left.6_{[37]}\right)$. The aim was to assess the success of business sustainability post start-up, understanding the contribution of volunteer support on business survivability and growth. $76 \%$ of the those who received full start-up support in 2012-13 were still running two years later, and 73\% three years later. These businesses have higher survival rates than "typical" businesses across the UK. The evaluation also found that the survival rate increased with age. Participants who received business mentoring but not a loan or grant were overall as likely to report their business was still surviving (74\%) compared to those who received both (71\%). $62 \%$ of those receiving full start-up support felt that accessing finance was the main obstacle in starting their business prior to engaging with the programme.

Lessons for other initiatives: One of the keys to 2. success for the Prince's Trust Enterprise Programme is its four stage approach that provides an increasing amount of support in each phase. Thus, more intensive support is provided to those who have demonstrated an interest and success. Another important element is the mentoring that is provided by volunteers. This individual support helps to increase the success rates for youth entrepreneurs. Finally, the programme offers certificates for participants who complete core elements of the programme. This can be helpful for young job seekers that decide not to pursue entrepreneurship but can demonstrate that they have acquired skills and experience that can be applied as an employee.

For more information, please see: https://www.princes-trust orq.uk/help-for-young-people/support-starting-business 


\section{Improve access to finance}

Goal

Addressing the undercapitalisation of youth-operated businesses by facilitating access to various sources of debt and/or equity financing can improve their chances of developing into sustainable businesses. There is also a need to improve the financial literacy skills of young people, particularly about business finance.

\section{Approach}

Many public youth entrepreneurship schemes provide participants with some form of financial support. This often includes, for example, grants, loans, or an allowance (i.e. regular payments to cover living costs). Two of the most common types of financial support offered to young entrepreneurs are nonrepayable grants and start-up loans.

Grant schemes generally have strict selection criteria in which entrepreneurs with feasible business plans, relevant qualifications and/or experience are provided with a small amount of funding. Grants often come with the condition of completing a training programme. Youth with prior entrepreneurship experience or high levels of educational attainment are more likely to receive grants than young people from disadvantaged backgrounds or with a lower level of education (Eurofound, 2016 $6_{[20]}$ ).
In the case of loans, governments essentially face two options in establishing programmes. First, they can offer credit directly from the public sector. The benefit of this approach is that the government maintains full control over the mandate and operation of the programme. An example of this approach is ENISA, a Spanish state-owned company that offers credit to youth entrepreneurs (Box 6). It offers loans with interest rates that can be reduced if certain business performance targets are met. The second option is that authorities can operate programmes that are managed by banks or other credit institutions, including offering loan guarantees for private sector loans. In dealing with private risk capital providers, public authorities can leverage private sector expertise and experience while increasing the supply of debt financing to young entrepreneurs (European Committee of Regions, 2017[38] $)$.

One type of loan is microcredit, which is typically considered to be a loan of up to EUR 25000 . When microcredit is packaged together with other support services, it is referred to as microfinance. Microfinance plays a central role in EU's 2020 Strategy for financial inclusion and inclusive growth. Microfinance schemes often specifically target population groups who experience greater difficulties in obtaining external finance including young people.

\section{Box 6. ENISA Young Entrepreneurs, Spain}

Target group: Entrepreneurs under 40 years old

Initiative types: Loans

Description: ENISA is a state-owned company under the responsibility of the General Directorate of Industry and SMEs in the Ministry of Industry, Commerce and Tourism. Its mandate is to provide financial support start-ups and young SMEs that are seeking to bolster their innovation activities.

The Young Entrepreneurs line of credit offers loans of EUR 25000 to EUR 75 000, repayable over seven years. The interest rate charged is the Euribor rate $+3.25 \%$, plus a variable rate (between three and six percentage points) that inversely depends on the profitability of the company. A bank endorsement is not needed to secure a loan.

Eligible firms are those that are under 24 months old and operated by someone under the age of 40 years old. The entrepreneurs are required to provide at least 50\% of the value of the approved loan in financial capital or own funds.
The loans can be used to acquire fixed assets and fund operating activities. Real estate and financial sectors are not eligible for loans.

Results achieved: A recent evaluation (Martí Pellón, $2018_{[39]}$ ) reported that the Young Entrepreneur Facility issued a total EUR 63.7 million to 1380 borrowers between 2009 and 2013. By 2015, these entrepreneurs had created 2494 additional new jobs. From a cost-benefit perspective, $57.6 \%$ of the principal borrowed had been paid back by June 2017 and the estimated cost per job created was EUR 3800.

Lessons for other initiatives: There are strong incentives for the young entrepreneurs to succeed because the cost of the loan is related to the success of the company. Those that are more profitable can lower interest rates.

For more information, please see: https://www.enisa.es/en 
A number of microfinance institutions have benefited from EU support through loans or guarantees from the European Progress Microfinance Facility, a microfinance initiative established in March 2010 with around EUR 200 million of funding from the European Commission and the European Investment Bank. The European Progress Microfinance Facility is closely coordinated with existing public policy instruments to support microfinance across the EU (European Parliament, $\left.2015_{[18]}\right)$. In developing economies, where such schemes are most widely used, recent evaluations suggest that "one size fits all" microcredit schemes tend not to be effective. Instead key aspects of the programmes have to be adapted to local conditions, e.g. repayment periods, grace periods, individual-liability contracts, and the use of technology (Karlan et al., 2016 $\left.6_{[40]}\right)$.

The European Progress Microfinance Facility has since been replaced by a second generation of EU-level financial instruments implemented through the EU's Employment and Social Innovation (EaSI) programme, which is managed indirectly by the European Commission. The current Microfinance and Social Entrepreneurship axis of EaSI ensures continuity in the support given to microcredit providers under Progress Microfinance and further extends its scope to intermediaries financing social enterprises.

A study by the European Commission on the implementation of the European Progress Microfinance facility argues for the geographical expansion of microloans and identifies a large unmet demand for microloans in the EU (European Commission, $\left.2014_{[41]}\right)$. A key success factor for expanding microloans is likely the use of guarantees for microfinance support.

Another type of financial support commonly offered to youth entrepreneurs is an allowance, which aims to help cover living expenses while they are setting up their business. This is most often used to support unemployed youth who are launching a business. Several evaluations highlight that this type of support can be a critical safety net during the first few months of training (Jones, Brinkley and Crowley, 2015 ${ }_{[22]}$ ). In many cases, financial support is offered as part of labour market activation measures in the form of subsidies aiming to foster business creation among the unemployed (European Parliament, $\left.2015_{[18]}\right)$.

An emerging phenomenon which has shown promising potential in "democratising finance" is crowdfunding where a project or a new business can raise small amounts of money from a large number of people, typically via the Internet (Mollick and Robb, 2016 $\left.{ }_{[42]}\right)$. Crowdfunding can be especially important in geographic locations far from urban centres with strong financial institutions (Sorenson et al., 2016 $6_{[43]}$ ). EU-level initiatives also aim to stimulate social entrepreneurship, notably through the EaSI programme under which EUR 193 million has been made available for the $2014-20$ period to facilitate access to microfinance and finance for social enterprise (European Parliament, 2015 ${ }_{[18]}$ ).

Improving access to finance can have an important role in supporting business development and growth, but policy makers also need to ensure that youth can use the funding appropriately. Several studies continue to show that many youth lack sufficient financial knowledge to operate a business or manage their own personal finances (Loke, Choi and Libby, 2015 $5_{[44]}$ ) (Xu and Zia, 2012[45]) (Johnson and Sherraden, $\left.2007_{[46]}\right)$. Recent concerns about student loan defaults and large amounts of student debt suggest that many young adults do not fully understand the nature of the financial decisions they are making with regards to paying for their education, or they may understand the implications of such borrowing but lack the financial capital necessary to pay for college (Loke, Choi and Libby, 2015 $\left.5_{[44]}\right)$.

This calls for a greater emphasis on strengthening financial literacy among youth, particularly related to business finance. A pilot programme which has been effective in increasing the financial capabilities is the MyPath Savings Pilot in the US (Loke, Choi and Libby, 2015 ${ }_{[44]}$ ). Although the programme is not directly related to entrepreneurship, it provides an example of approaches to help young people better understand financial decisions. 


\section{Support the development of entrepreneurship networks}

Goal

Youth typically have little experience in the labour market and therefore have had fewer opportunities to build professional networks. Policy makers can help youth overcome this disadvantage by opening up opportunities for them to strengthen and expand their entrepreneurship networks.

\section{Approach}

Entrepreneurship networks are very valuable resources because they can facilitate access to resources such as financing, business partners, suppliers, employees and customers. They can also be a source of inspiration for new products, services, processes, organisational methods and business practices, and can also influence the perception of the desirability and feasibility of entrepreneurship (OECD/EU, $\left.2015_{[47]}\right)$.

In the context of entrepreneurship, networks are groups of interconnected entrepreneurs, business service providers and various other relevant people (e.g. customers) who can be accessed by entrepreneurs for information and ideas in reciprocal relationships (OECD/EU, 2015 $\left.{ }_{[47]}\right)$.

For youth, entrepreneurship networks can be difficult to build because they lack professional experience. As new entrepreneurs, youth typically start building their networks around their friends, family and teachers. However, policy makers can help expand these personal networks to include other entrepreneurs to increase learning opportunities and value of the interactions.

There are four basic approaches that public policy initiatives tend to use in supporting network development for youth.

1. Create dedicated youth entrepreneurship networks. This approach brings youth entrepreneurs together through in-person events such as meetings, seminars, conferences and social events. Engagement can be maintained through newsletters and online interactions. The strength of this approach is that trust can easily be formed between network members since members would be typically be all young entrepreneurs. The drawback to creating youth-focussed entrepreneurship networks is that members would typically face similar challenges and would not necessarily be well-equipped to support each other. Therefore, network managers would need to build linkages with other entrepreneurs from the local business community, as well as other business support organisations.
2. Create youth entrepreneurship networks around another intervention. This approach uses another support initiative (e.g. entrepreneurship training) as the anchor for the network. These networks are typically easy to set up since there is already a commonality between the entrepreneurs. The strength of this approach is that the network can reinforce the target business development support. The downside of this approach is that the networks tend to lead to short-term relationships since they are built around other interventions. An example of this approach is YES!Delft in the Netherlands (Box 7), which built a network for student and academic entrepreneurs who participate in its incubator programme.

\section{Create specialised youth entrepreneurship} networks (e.g. Young tech entrepreneurs). These networks operate much like other youth entrepreneurship networks, but they are focussed on a particular type of business. The value of these networks is that the activities are much more tailored to the needs of network members, including the organisation of seminars and workshops. However, these networks can be resource intensive given the integration of business development support.

\section{Create virtual youth entrepreneurship networks.} Online networks are easily created and can be embedded into an existing social media platform. While online networks can help improve accessibility to others, this ease of access can also result in a lower commitment to building trust and reciprocal relationships. One of the challenges faced by virtual networks is maintaining active engagement of network members. However, they can be managed with little operating costs and allow a great deal of flexibility on how and when members interact.

Regardless of the approach used, there are a number of key factors that need to be considered when designing and implementing initiatives to help youth entrepreneurs strengthen their networks, including objectives, frequency and type of interaction, target size, and management of the network.

Effective network management requires strong buy-in from youth. To achieve this, networks need an active manager who can animate the network and maintain regular communication with members. It is also important to allow youth to participate in networks in various ways, e.g. online, face-to-face.

In addition, policy makers can have a role in supporting entrepreneurship networks that have been created and developed by entrepreneurs and businesses. This includes promotion, referrals from public entrepreneurship programmes, and financial support. 


\section{Box 7. YES!Delft, The Netherlands}

Target group: University students and young professionals in the tech industry.

$\underline{\square}$

Intervention type: A comprehensive support package, including business incubation, networks and training.

$\{$ S Description: YES!Delft was started in the early 2000s by the Delft University of Technology (TU Delft), the City of Delft and the Dutch Organisation for Applied Scientific Research (TNO). As of 2018, there were 17 local national and international organisations sponsoring the incubator programme. It has supported over 200 tech start-ups in the Netherlands since it was founded in 2005 (YES!Delft, 2018 ${ }_{[48]}$ ).

The mission of YES!Delft is to build tomorrow's leading firms. It offers entrepreneurship courses for higher education students, "LaunchLab" to help scientists and business professionals develop a business idea into a viable business model, and the "Incubation Programme" for entrepreneurs who have already done market testing and are ready to build their business.

In addition to seminars, coaching and mentoring, business consulting, the Incubation Programme also puts significant effort into network building. YES!Delft offers an extensive network with experienced entrepreneurs, service providers, investors and technical experts. Programme managers regularly organise network meetings and events for entrepreneurs, government officials, service providers and investors. These include a large annual event, as well as smaller social meetings where entrepreneurs can meet potential investors and partners in a more informal setting.

Results achieved: As of 2015, YES!Delft has supported over 140 start-ups of which $82 \%$ are still operating. The high success rate is attributed to the comprehensive nature of the support program and the strong connections between entrepreneurs and external investors.

Lessons for other initiatives: A key success factor O. for the initiative is that it engages youth in its management. The YES!Delft Student Board was established to maintain effective linkages with the university and student body. Five students serve on the board each year.

For more information, please see: https://www.yesdelft.com/ 


\section{KEY CONSIDERATIONS FOR DESIGNING YOUTH ENTREPRENEURSHIP POLICIES AND PROGRAMMES}

\section{Participant selection}

One of the key questions for entrepreneurship policies aimed at youth is: "who should be supported?". Many schemes are aimed at stimulating and supporting innovation and therefore are targeted at higher education graduates, who may have greater potential to go on to create an innovative business that can create many jobs and generate substantial economic activity. However, other schemes are developed to offer unemployed youth another option for being active in the labour market. Thus, youth entrepreneurship support can appear as a decision between supporting those with the greatest chances of success or those who are the most disadvantaged in the labour market. Both publics need to be addressed, but the design of the schemes could be different.

Regardless of the approach, a basic principle is that policy makers cannot "pick winners" because it is very difficult to predict the sustainability and impact that any particular start-up will have. Furthermore, attention has to be paid to be the possibility of deadweight effects. ${ }^{1}$ If programmes target those individuals who have characteristics most likely to be

\section{Packaging of support offers}

The introduction of the Youth Guarantee and the YEI have led to an increase in youth entrepreneurship support programmes in the EU. As of 2015, about half of EU Member States made entrepreneurship a strategic priority in their Youth Guarantee Implementation Plans, particularly in Southern Europe where young people are more economically vulnerab (European Parliament, $\left.2015_{[18]}\right)$. A common feature of youth entrepreneurship support is the offer of combinations of financial support with "soft" support in the form of entrepreneurship training, advisory services, mentoring and/ or coaching (European Parliament, 2015 $[18])$.

Traditionally, support offers that bundle complementary support together appear to be more effective at developing sustainable businesses (Halabisky, 2012[49]). Similarly, a recent meta-analysis by the European Parliament found that youth entrepreneurship strategies that combine different types of support have a greater impact than those offered as stand-alone actions (European Parliament, 2015 $\left.5_{[18]}\right)$. Similar associated with business success, they may also focus on those most likely to be successful even without the support. In contrast, schemes that target unemployed and disadvantaged youth tend to have lower deadweight effects but also lower success rates for the businesses created.

One way to minimise deadweight effects is to incorporate selfselection mechanisms into support programmes. An example of an effective approach is the one used by the Prince's Trust Enterprise Programme (Box 5), which uses a "funnel". At the outset, very light support is provided to a large number of entrepreneurs. Follow-up support is increasingly intensive and provided to those who can demonstrate motivation and success. This offers a way of delivering the most costly support to the few with the strongest motivations and track records. Furthermore, it reduces exposure to unnecessary risk for those with little chances of successfully creating a sustainable business. This approach can be applied to support that is targeted at high potential youth entrepreneurs, as well as those seeking an alternative route into work.

results were identified in an international review of youth entrepreneurship programme evaluations (Tendongho, 2015 $\left.{ }_{[50]}\right]$.

A more difficult issue is striking the right balance between different types of support within the packages. In other words, where should governments place the greatest emphasis within a comprehensive programme - financial support, entrepreneurship training, coaching and mentoring, or network building? If the objectives are to support youth in business creation, evaluation evidence tends to indicate that financial supports frequently have the greatest impact, while "soft" supports are the most appreciated by youth entrepreneurs (Eurofound, 2016 $6_{[20]}$ ). However, if the objective is to develop entrepreneurial mindsets, a greater emphasis should be placed on training and activities that allow youth to experience entrepreneurship (e.g. business competitions). 


\section{Displacement effects}

Displacement effects occur when some entrepreneurs and enterprises that receive public support grow at the expense of others. Thus, some of the benefits where public support leads to the creation and growth of new businesses may be offset by closures or contractions of other businesses, reducing the benefits for the economy and labour market overall. To understand the full impacts of policy, evaluations must therefore consider possible displacement effects as well as the positive impacts on participant firms and entrepreneurs (Behrenz, Delander and Månsson, 2012 $\left.2_{[51]}\right)$. In general, little is known about the displacement effects of youth entrepreneurship initiatives (Jones, Brinkley and Crowley, 2015[22] $)$.

One example of where displacement effects were estimated was an evaluation performed on the business start-up support scheme in Sweden 2006-07 (Norgren et al., 2008 ${ }_{[52]}$ ). It estimated that approximately $25 \%$ of supported firms believed that they had received an advantage compared with their competitors, suggesting some market distortion. However, a later evaluation of the same programme did not find any statistically significant displacement effects (Behrenz, Delander and Månsson, 2012 $2_{[51]}$ ).

Very few evaluations of start-up support programmes have included data on potential displacement effects because these effects are difficult to fully assess (Cueto and Mato, 2006 $6_{[53]}$ ). This is particularly true with the rapid emergence of the digital economy that expands market boundaries.

Policy makers nevertheless need to be aware of the displacement issue and consider it during policy design. Policy and programme evaluations should also consider and estimate - to the extent possible - displacement effects. It is likely that the displacement effects of youth entrepreneurship policies will be lower in the case of initiatives that encourage innovative projects and steer entrepreneurs away from excess supply industries.

\section{Digital delivery of entrepreneurship support}

Young people have higher levels of digital skills than other age cohorts (OECD, 2015 $\left.{ }_{[54]}\right)$. This opens up a new avenue for policy makers to deliver information about entrepreneurship and support for business creation to youth, increasing the reach and potentially decreasing the costs of delivering support. The European Commission notes in its Communication on Rethinking Education that digital learning trends in Open Educational Resources (OER) are enabling large changes in education and that Member States should scale up the use of ICT-supported learning and access to high quality OER (European Commission, 2012 ${ }_{[32]}$ ).

Entrepreneurship teaching in higher education has been experimenting with digital delivery for several years and can offer some insights for wider application. While there is likely potential for moving some aspects of youth entrepreneurship support online, other aspects are less appropriate to digitalise. It is likely possible that public programmes could further use digital technologies to screen applicants and deliver some training through online modules. However, other activities are more beneficial with face-to-face interactions. Building relationships within networks is more beneficial when the interactions require greater effort, such as attending an in-person meeting or event. Similarly, coaching and mentoring tends to be more effective when delivered though face-to-face interactions (OECD/EU, 2014[36).

The profile of the targeted youth entrepreneur must also be considered. A recent survey by the Prince's Trust suggests that more than $50 \%$ of NEETs do not consider themselves very good at using computers compared to $71 \%$ of a wider youth sample and that about $25 \%$ of NEETs feel unconfident about creating a spreadsheet (Jones, Brinkley and Crowley, 2015 [22]). This indicates that digital solutions must be user-friendly and accessible through a range of devices (e.g. computers, smartphones, tablets). 


\section{CONCLUSIONS}

Interest in youth entrepreneurship has increased in recent years among policy makers, largely due to high youth unemployment and deteriorating labour market outcomes for young adults and recent graduates. At the same time, there is a growing momentum behind the implementation of entrepreneurship education in the EU. The desire is not only to stimulate entrepreneurial attitudes, mindsets and skills that could lead to business creation and innovation, but also to build transversal skills that will help the future labour force to be flexible and adaptable. This last point is particularly important given that business creation is not a suitable activity for everybody.

Policy makers have a large range of instruments at their disposal to support youth in business creation. These include offering education and training, facilitating access to grants and repayable loans, matching entrepreneurs with coaches and mentors, and building entrepreneurship networks. Evaluation evidence suggests that programmes and initiatives are more effective when complementary instruments are offered together. However, it is less clear whether there should be a greater emphasis on offering access to finance or delivery of entrepreneurship skills. Recent research suggests that financial supports tend to have a greater impact on the sustainability of the business but evaluations note that training, coaching and mentoring are often more valued by youth entrepreneurs. This evidence base needs to be strengthened, particularly given the recent increase in the number of youth entrepreneurship programmes.

Another important question for policy makers is how to decide which young people should be supported in entrepreneurship. In general, policy makers should not provide start-up support to "false" self-employed workers, nor should they attempt to select "winners" since it is hard to predict which business start-ups will be successful and which will not. The experience of the Prince's Trust Enterprise Programme illustrates the "funnel" approach, which offers "light" support to a large number of participants and more intensive support to those who demonstrate successes throughout the development of their idea and project. This phased approach uses both self-selection and competitive mechanisms to determine where support is allocated. It also eliminates exposing youth to unnecessary risk when they have little chance for success. Another important feature that this initiative highlights is the need to offer flexibility to youth so that they can determine their own pathway through the programme. This helps ensure that the programme is relevant and attractive to potential participants.

It is also important for policy makers to consider how support programmes are delivered. Instead of delivering all initiatives as "top-down support" it could be very beneficial to engage youth and youth organisations in the design of youth entrepreneurship support. Youth organisations have active membership rosters, institutional infrastructure, and legitimacy among many young individuals in speaking for them and organising activities on their behalf. Using such organisations both to identify support needs in local communities but especially for organising support design and delivery may enhance impact as well as the costefficiency of initiatives.

The OECD Local Economic and Employment Development Committee identified and discussed a set of good practices for youth entrepreneurship policy at its 65th Session (13-14 November 2014). This offers a framework for policy makers in designing and implementing a comprehensive support system for youth entrepreneurs (Box 8). Good practices are also identified in the Better Entrepreneurship Policy Tool (www.betterentrepreneurship.eu), developed by the OECD and the European Commission, which is an interactive tool for policy makers and other stakeholders. It includes a self-assessment exercise that helps users identify the strengths and areas for improvement in youth entrepreneurship support and connects them to relevant policy guidance and case study examples. The tool also includes modules for women's entrepreneurship, migrant entrepreneurship, entrepreneurship by the unemployment, and social entrepreneurship. 


\section{Box 8. OECD good practices for youth entrepreneurship policy}

\section{Generic principles:}

1. Select beneficiaries of youth entrepreneurship programmes carefully and tailor the support provision to the needs of youth.

- Extensive support should be low cost and offered widely

- Intensive support should be competitive or filtered to select recipients that are motivated and most likely to succeed

2. Use youth entrepreneurship policies and programmes to promote creativity and innovation.

- Seek (even low level) innovation in supported business projects (including organisational, marketing, green, social)

3. Recognise that different policy interventions complement and reinforce each other.

. Offer combined access to finance, training, mentoring, and networking

- Ensure education, economic and labour policies are co-ordinated and complementary

- Identify gaps and synergies across stakeholders

4. Consider adapting mainstream programmes as an alternative to youth-specific actions.

5. Engage youth and youth organisations in the design and implementation of youth entrepreneurship policies and programmes.

- Communicate with youth through appropriate channels

- Consult youth organisations in policy design

- Leverage stakeholder knowledge and experience

6. Appraise and evaluate youth entrepreneurship policies and programmes, making adjustments when design or implementation can be improved.

- Identify intervention needs, targets and expected impacts

- Evaluate results and adjust the approach

- Seek employability as well as venture creation outcomes

- Measure long-term as well as short-term impacts

\section{Strategy for supporting youth entrepreneurship:}

1. Develop a vision for youth entrepreneurship support.

- Embed entrepreneurship promotion and support within youth employment strategies

2. Communicate the objectives of youth entrepreneurship policies and programmes to youth, youth organisations and the community.
3. Government actors and other stakeholders have defined, complementary roles in supporting youth entrepreneurship.

\section{Building a supportive institutional environment:}

1. Ensure that the regulatory environment does not discriminate or provide disincentives for youth entrepreneurship.

. Be supportive of youth entrepreneurship in welfare, tax and regulatory systems.

- Ensure that bankruptcy laws do not prevent young entrepreneurs from having a second chance.

2. Promote positive image of entrepreneurship to build a culture of entrepreneurship amongst youth.

- Inform youth and society about the potential of youth entrepreneurship.

- Celebrate young entrepreneurs as role models.

3. Ensure that youth can access information and resources about entrepreneurship.

- Provide ready information on how to start up.

- Make business start-up support easily accessible to youth.

\section{Improving entrepreneurship skills:}

1. Provide entrepreneurship education in schools, vocational training and higher education.

- Develop entrepreneurial mind sets as well as new ventures

- Provide opportunities to learn through experience (e.g. business simulations and competitions)

- Include low educational achievers

2. Provide coaching and mentoring for young people with interest and potential for sustainable projects.

- Use an appropriate matching mechanism to ensure a good fit between coachee/mentee and coach/mentor

3. Encourage networking.

- Create links with other young entrepreneurs, senior entrepreneurs, investors and partners

\section{Facilitating access to finance:}

1. Provide financial literacy education to all youth.

2. Ensure youth can access loans and microfinance.

- Use grants when loans are not feasible

3. Encourage alternative financing methods such as guarantees, crowdfunding, peer-to-peer lending, business angel investment.

4. Complement financial support with business training and mentoring. 


\section{SUGGESTED FURTHER READING}

OECD/European Union (2019), The Missing Entrepreneurs 2019: Policies for Inclusive Entrepreneurship, OECD Publishing, Paris. Elmoznino Laufer, M. and K. Wennberg (2018), “Supporting Youth in Entrepreneurship”, prepared for the OECD Local Economic and Employment Development Programme, Paris.

\section{REFERENCES}

Bacigalupo, M. et al. (2016), EntreComp: The Entrepreneurship Competence Framework, Publication Office of the European Union, Luxembourg, http://dx.doi.org/10.2791/593884.

Behrenz, L., L. Delander and J. Månsson (2012), “Start-up Subsidies in Sweden: Treatment, Deadweight and Direct Displacement Effects”, No. 2012-17, Linnaeus University Centre for Labour Market Discrimination Studies.

Berger, A. and G. Udell (1998), "The economics of small business finance: The roles of private equity and debt markets in the financial growth cycle”, Journal of Banking \& Finance, Vol. 22/6-8, pp. 613-673.

Caliendo, M. and S. Künn (2011), "Start-up subsidies for the unemployed: Long-term evidence and effect heterogeneity", Journal of Public Economics, Vol. 95/3-4, pp. 311-331.

Carcillo, S. et al. (2015), "NEET Youth in the Aftermath of the Crisis: Challenges and Policies", OECD Social, Employment and Migration Working Papers, No. 164, OECD Publishing, Paris, https://dx.doi.org/10.1787/5js6363503f6-en.

Cueto, B. and J. Mato (2006), "An Analysis of Self-Employment Subsidies with Duration Models", Applied Economics, Vol. 38/1, pp. 23-32.

Davidsson, P. and B. Honig (2003), "The role of social and human capital among nascent entrepreneurs", Journal of Business Venturing, Vol. 18/3, pp. 301-331.

Eesley, C. and Y. Wang (2017), "Social influence in career choice: Evidence from a randomized field experiment on entrepreneurial mentorship", Research Policy, Vol. 46/3, pp. 636-650.

Elert, N., F. Andersson and K. Wennberg (2015), "The impact of entrepreneurship education in high school on long-term entrepreneurial performance”, Journal of Economic Behavior \& Organization, Vol. 111, pp. 209-223.

Enterprise Europe Network (2018), Enterprise Europe Network (About), https://een.ec.europa.eu/about/about

(accessed on 1 August 2018).

EU (2013), Entrepreneurship Action Plan 2020: Reigniting the entrepreneurial spirit in Europe, Communication from the Commission to the European Parliament, the Council, the European Economic and Social Committee, and Committee of the Regions, https://eur-lex.europa.eu/legal-content/EN/TXT/PDF/?uri=CELEX:52012DC0795\&from=EN.

Eurofound (2019), NEETs, https://www.eurofound.europa.eu/topic/neets (accessed on 19 April 2019).

Eurofound (2016), Start-up support for young people in the EU: From implementation to evaluation, https://www. eurofound.europa.eu/publications/report/2016/labour-market-business/start-up-support-for-young-people-in-the-eu-fromimplementation-to-evaluation

Eurofound (2015), Youth Entrepreneurship in Europe: Values, attitudes, polices, https://www.eurofound.europa.eu/publications/ report/2015/labour-market/youth-entrepreneurship-in-europe-values-attitudes-policies.

European Commission (2018), "Digital Education Action Plan", Communication from the Commission to the European Parliament, the Council, the European Economic and Social Committee and the Committee of the Regions, COM(2018) 22 final.

European Commission (2018), Youth Employment Initiative (YEI), https://ec.europa.eu/social/main.jsp?catld=1176 (accessed on 20 January 2019).

European Commission (2017), Employment and Social Developments in Europe 2017, Publications Office of the European Union, Luxembourg, http://dx.doi.org/10.2767/144714.

European Commission (2017), Taking the future into their own hands: Youth work and entrepreneurial learning, https://ec.europa.eu/youth/news/2017/new-study-published-youth-work-and-entrepreneurial-learning en.

European Commission (2014), Report from the Commission to the European Parliament, the Council, the European Economic and Social Committee and the Committee of the Regions: Implementation of the European Progress Microfinance Facility - 2013. 
European Commission (2013), Entrepreneurship in the EU and Beyond, Flash Eurobarometer No. 354, http://ec.europa.eu/ commfrontoffice/publicopinion/flash/fl 354 en.pdf.

European Commission (2012), "Rethinking Education: Investing in skills for better socio-economic outcomes", Communication from the Commission to the European Parliament, the Council, the European Economic and Social Committee and the Committee of the Regions, COM(2012) 669 final.

European Commission (forthcoming), Study supporting the evaluation and development of youth entrepreneurship policies and actions, report prepared by Ernst \& Young for DG Employment, Social Affairs and Inclusion.

European Commission/EACEA/Eurydice (2016), Entrepreneurship Education at School in Europe, Publications Office of the European Union, Luxembourg.

European Committee of Regions (2017), Youth initiative: a framework for youth entrepreneurship, https://cor.europa.eu/en/ documentation/studies/Documents/Youth initiative/youth-initiative.pdf.

European Parliament (2015), The Availability and Use of Assistance for Entrepreneurship to Young People, http://www.europarl. europa.eu/RegData/etudes/STUD/2015/542200/IPOL STU\%282015\%29542200 EN.pdf.

European Union (2013), Council Recommendation of 22 April 2013 on establishing a Youth Guarantee, https://eur-lex.europa. eu/LexUriServ/LexUriServ.do?uri=0J:C:2013:120:0001:0006:EN:PDF.

Eurostat (2018), Labour Force Survey, https://ec.europa.eu/eurostat/web/lfs/data/database (accessed on 1 December 2018).[3] Geldhof, G. et al. (2014), "Fostering Youth Entrepreneurship: Preliminary Findings From the Young Entrepreneurs Study", Journal of Research on Adolescence, Vol. 24/3, pp. 431-446.

Global Entrepreneurship Monitor (GEM) (2018), Special tabulations of the 2013-17 adult population surveys from the Global Entrepreneurship Monitor.

Halabisky, D. (2012), "Entrepreneurial Activities in Europe - Youth Entrepreneurship”, OECD Employment Policy Papers, No. 1, OECD Publishing, Paris, https://dx.doi.org/10.1787/5jxrcmlf2f27-en.

Hite, J. (2005), "Evolutionary processes and paths of relationally embedded network ties in emerging entrepreneurial firms", Entrepreneurship Theory and Practice, Vol. 29/1, pp. 113-144.

Johnson, E. and M. Sherraden (2007), “From financial literacy to financial capability among youth”, Journal of Sociology \& Social Welfare, Vol. 34/3, pp. 119-146.

Jones, K., I. Brinkley and L. Crowley (2015), Going solo: Does self-employment offer a solution to youth unemployment?, The Work Foundation, Lancaster.

Karlan, D. et al. (2016), "Research and impacts of digital financial services”, No. No. w22633, National Bureau of Economic Research.

Laufer, M. and K. Wennberg (2017), "Entrepreneurship from unemployment? The efficiency and effectiveness of selfemployment subsidies”, in Laufer, M. (ed.), Essays on Finance for Start-ups, Stockholm School of Economics, Stockholm.

Lockett, N. et al. (2015), The Bermuda Triangle in Entrepreneurship Education: The Role of Social Capital in Entrepreneurial Learning, Institute for Small Business and Entrepreneurship, Glasgow.

Loke, V., L. Choi and M. Libby (2015), "Increasing Youth Financial Capability: An Evaluation of the MyPath Savings Initiative", The Journal of Consumer Affairs, Vol. 49/1, pp. 97-126.

Martí Pellón, J. (2018), Valoración del impacto económico y social de los préstamos otorgados por Enisa entre 2005 y 2013, https://cdn.enisa.es/News/92918B2CA2F3007A19CEC18958E34E5D/ATTACHMENT/7D7A2806575F04C401417D57BFAE92F5/ 2d663e12c4cd93e0fff9c16b1bfa66914373a761.pdf.

Ministry for National Economy (Hungary) (2015), EU funding of more than HUF 4000bn available for direct economic development, Hungarian Ministry for National Economy News, http://www.kormany.hu/en/ministry-for-national-economy/news/ eu-funding-of-more-than-huf-4000bn-available-for-direct-economic-development (accessed on 18 February 2015).

Mollick, E. and A. Robb (2016), “Democratizing innovation and capital: The role of crowdfunding”, California Management Review, Vol. 58/2, pp. 72-87.

Norgren, C. et al. (2008), Stöd till start av näringsverksamhet, Ett framgångsrikt program, Riksrevisionen,

Riksdagstryckeriet.

OECD (2018), Good Jobs for All in a Changing World of Work: The OECD Jobs Strategy, OECD Publishing, Paris,

https://dx.doi.org/10.1787/9789264308817-en 
OECD (2018), Job Creation and Local Economic Development 2018: Preparing for the Future of Work, OECD Publishing, Paris, https://dx.doi.org/10.1787/9789264305342-en.

OECD (2018), OECD Economic Outlook, Volume 2018 Issue 2, OECD Publishing, Paris, https://dx.doi.org/10.1787/eco outlookv2018-2-en.

OECD (2016), Supporting youth entrepreneurship in Hungary, OECD, Paris.

OECD (2015), Adults, Computers and Problem Solving: What's the Problem?, OECD Skills Studies, OECD Publishing, Paris, https://dx.doi.org/10.1787/9789264236844-en.

OECD/EU (2017), The Missing Entrepreneurs 2017: Policies for Inclusive Entrepreneurship, OECD Publishing, Paris, https://dx.doi.org/10.1787/9789264283602-en.

OECD/EU (2015), Policy Brief on Expanding Networks for Inclusive Entrepreneurship, OECD, Paris, https://doi.org/10.1787/23114886.

OECD/EU (2014), The Missing Entrepreneurs 2014: Policies for Inclusive Entrepreneurship in Europe, OECD Publishing, Paris, https://dx.doi.org/10.1787/9789264213593-en.

Oosterbeek, H., M. van Praag and A. ljsselstein (2010), "The impact of entrepreneurship education on entrepreneurship skills and motivation", European Economic Review, Vol. 54/3, pp. 442-454.

Oreland, C. (2016), Företagande bland unga och betydelsen av egen förmögenhet, Svenskt Näringsliv.

Pantea, M. (2014), Youth entrepreneurship, EU - CoE youth partnership policy sheet, https://pjp-eu.coe.int/ documents/1017981/1668235/Entrepreneurship-2014.pdf/ed4968a3-e515-4d97-b9a6-30fbbba1857f.

Parker, S. (2009), The economics of self-employment and entrepreneurship, Cambridge University Press, Cambridge.

Politis, D. (2015), "The process of entrepreneurial learning: A conceptual framework", Entrepreneurship Theory and Practice, Vol. 29/4, pp. 399-424.

Rantanen, T. and E. Järveläinen (2016), "Finnish Young People's Attitudes towards and Perceptions of Entrepreneurship: An evaluation of the impact of Youth entrepreneurship theme year", Studia Oeconomica Posnaniensia, Vol. 4/5, pp. 7-24.

Rosa, P. (2003), "Hardly likely to make the Japanese tremble - The businesses of recently graduated university and college entrepreneurs", International Small Business Journals, Vol. 21/4, pp. 435-459.

Schmillen, A. and M. Umkehrer (2017), "The scars of youth: Effects of early-career unemployment on future unemployment experience”, International Labour Review, Vol. 156/3-4, pp. 465-494.

Schøtt, T., P. Kew and M. Cheraghi (2015), Future Potential: A GEM perspective on youth entrepreneurship 2015, http://www. innovacion.cl/wp-content/uploads/2015/08/gem-2015-youth-report-1436523546.pdf.

Sorenson, O. et al. (2016), “Expand innovation finance via crowdfunding”, Science, Vol. 354/6319, pp. 1526-1528.

Tendongho, C. (2015), A Systematic Review on the Effectiveness of Youth Entrepreneurship Programs, SSRN, https://ssrn.com/ abstract=2948691 or http://dx.doi.org/10.2139/ssrn.2948691.

Wavehill (2016), Trust in Business: How Prince's Trust support increases business sustainability, https://www.princes-trust.org. uk/Document Trust-in-Business-report.pdf.

Xu, L. and B. Zia (2012), Financial literacy around the world: an overview of the evidence with practical suggestions for the way forward, The World Bank, https://elibrary.worldbank.org/doi/abs/10.1596/1813-9450-6107. 


\section{Getting in touch with the EU}

\section{In person}

All over the European Union there are hundreds of Europe Direct information centres. You can find the address of the centre nearest you at: https://europa.eu/european-union/contact_en

\section{On the phone or by email}

Europe Direct is a service that answers your questions about the European Union. You can contact this service:

- by freephone: 0080067891011 (certain operators may charge for these calls),

- at the following standard number: +3222999696 or

- by email via: https://europa.eu/european-union/contact_en

\section{Finding information about the EU}

\section{Online}

Information about the European Union in all the official languages of the EU is available on the Europa website at: https://europa.eu/european-union/index_en

\section{EU publications}

You can download or order free and priced EU publications at: https://publications.europa.eu/en/publications. Multiple copies of free publications may be obtained by contacting Europe Direct or your local information centre (see https://europa.eu/european-union/contact_en).

\section{EU law and related documents}

For access to legal information from the EU, including all EU law since 1952 in all the official language versions, go to EUR-Lex at: http://eur-lex.europa.eu

\section{Open data from the EU}

The EU Open Data Portal (http://data.europa.eu/euodp/en) provides access to datasets from the EU. Data can be downloaded and reused for free, both for commercial and non-commercial purposes.

\section{Getting in touch with the EU / finding info about the EU} HOW TO OBTAIN OECD PUBLICATIONS

- The OECD library: http://www.oecd-ilibrary.org

- The OECD Bookshop online: http://www.oecdbookshop.org 
This policy brief on youth entrepreneurship was produced by the OECD and the European Commission. It explores the scale and nature of entrepreneurship activities undertaken by youth, and describes the main barriers faced. The brief provides an overview of the main policy actions that can be used to support youth entrepreneurship, including awareness-raising activities (e.g. role models, business competitions), entrepreneurship education and training, coaching and mentoring, improving access to finance, and entrepreneurship network development.

Policy briefs are short reports designed for policy makers and practitioners which are part of a series of documents produced by the OECD and the European Commission on inclusive entrepreneurship. The series includes policy briefs on a range of topics including for example youth entrepreneurship, senior entrepreneurship, evaluation of inclusive entrepreneurship programmes, access to business start-up finance for inclusive entrepreneurship and entrepreneurship by the disabled as well as a series of publications on 'The Missing Entrepreneurs'. The briefs can be accessed at: http://www.oecd.org/employment/leed/inclusiveentrepreneurs-in-europe.htm. 